PECEIVED

AUG 161996

OSTI

Comparison of Neptunium Sorption Results

Using Batch and Column Techniques

Yucca Mountain Site Characterization Program

Milestone 3041 for the United States Department of Energy under contract W-7405-ENG-36. 


\section{DISCLAIMER}

Portions of this document may be illegible in electronic image products. Images are produced from the best available original document. 


\section{DISCLAIMER}

This report was prepared as an account of work sponsored by an agency of the United States Government. Neither the United States Government nor any agency thereof, nor any of their employees, makes any wartanty, express or implied, or assumes any legal liability or responsibility for the accuracy, completeness, or usefulness of any information, apparatus, product, or process disclosed, or represents that its use would not infringe privately owned rights. Reference herein to any specific commercial product, process, or service by trade name, trademark, manufacturer, or otherwise does not necessarily constitute or imply its endorsement, recommendation, or favoring by the United States Government or any agency thereof. The views and opinions of authors expressed herein do not necessarily state or reflect those of the United States Government or any agency thereof. 
Comparison of Neptunium Sorption Results

Using Batch and Column Techniques

Yucca Mountain Site Characterization Program

Milestone 3041

Inés R. Triay

Armando C. Furlano

Sidney C. Weaver

Steve J. Chipera

David L. Bish

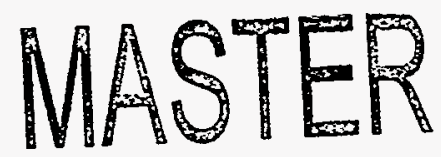




\title{
COMPARISON OF NEPTUNIUM SORPTION RESULTS USING BATCH AND COLUMN TECHNIQUES
}

\author{
Yucca Mountain Site Characterization Program Milestone 3041
}

\author{
by \\ Inés R. Triay, Armando C. Furlano, Sidney C. Weaver, \\ Steve J. Chipera, and David L. Bish
}

\begin{abstract}
We used crushed-rock columns to study the sorption retardation of neptunium by zeolitic, devitrified, and vitric tuffs typical of those at the site of the potential high-level nuclear waste repository at Yucca Mountain, Nevada. We used two sodium bicarbonate waters (groundwater from Well J-13 at the site and water prepared to simulate groundwater from Well UE-25p \#1) under oxidizing conditions. It was found that values of the sorption distribution coefficient, $K_{\mathrm{d}}$, obtained from these column experiments under flowing conditions, regardless of the water or the water velocity used, agreed well with those obtained earlier from batch sorption experiments under static conditions. The batch sorption distribution coefficient can be used to predict the arrival time for neptunium eluted through the columns. On the other hand, the elution curves showed dispersivity, which implies that neptunium sorption in these tuffs may be nonlinear, irreversible, or noninstantaneous. As a result, use of a batch sorption distribution coefficient to calculate neptunium transport through Yucca Mountain tuffs would yield conservative values for neptunium release from the site. We also noted that neptunium (present as the anionic neptunyl carbonato complex) never eluted prior to tritiated water, which implies that charge exclusion does not appear to exclude neptunium from the tuff pores. The column experiments corroborated the trends observed in batch sorption experiments: neptunium sorption onto devitrified and vitric tuffs is minimal and sorption onto zeolitic tuffs decreases as the amount of sodium and bicarbonate/carbonate in the water increases.
\end{abstract}

\section{INTRODUCTION}

The transport of ${ }^{237} \mathrm{~Np}$ through tuffs is of major importance in assessing the performance of a potential high-level nuclear waste repository at Yucca Mountain, Nevada. Uranium in nuclear reactors produces ${ }^{237} \mathrm{~Np}$, which has a half-life of $2.14 \times 10^{6}$ years. Nitsche et al. (1993 and 1994) reported that neptunium has a higher solubility in groundwaters from Yucca Mountain than other actinides (such as plutonium and americium). The high solubility of neptunium combined with its extremely limited sorption onto Yucca Mountain tuffs (Thomas 1987) makes this radionuclide a high priority in the transport studies of the Yucca Mountain Site Characterization Project.

Generally, batch sorption experiments are used to identify sorption mechanisms and to obtain sorption distribution coefficients (Triay et al. 1996a and 1996b). Such experiments are fast, easy, and inexpensive compared to other types of sorption experi- 
ments. In this study, we attempted to verify the results of earlier batch sorption measurements by performing crushed-tuff column studies under flowing conditions without significantly changing the surface properties of the tuff. By comparing differences with the batch sorption measurements, these studies would be most sensitive to multiple species formation, colloid formation, and any other geochemical reactions (such as changes in surface reactivity due to agitation) not adequately described by batch sorption distribution coefficients. In these crushed-tuff column experiments, we investigated mass transfer kinetics by studying radionuclide migration as a function of water velocity.

Column elution curves can be characterized by two parameters: the time of arrival of the radionuclide eluted through the column and the broadness (dispersion) of the curve. The arrival time depends on the retardation factor, $R_{\mathrm{f}}$, which, for soluble radionuclides, depends, in turn, on the sorption distribution coefficient, $K_{\mathrm{d}}$. Significant deviations (those larger than expected based on sampling variability) in arrival time from that predicted on the basis of the batch distribution coefficients indicate one of the following problems:

- the presence of more than one chemical species that are not readily exchanged and that have different selectivities in tuff minerals,

- the presence of the radionuclide as a colloid,

- extremely slow sorption kinetics,

- nonreversibility of the sorption process, and

- solubility effects due to the presence of solids.

The broadness, or apparent dispersion, of the curve depends on

- the kinetics and reversibility of sorption, and

- the linearity of the isotherm that describes the dependence of sorption on radionuclide concentration.

The main goal of our study was to test the necessary assumptions made in using values of the sorption distribution coefficient, $K_{\mathrm{d}}$, (determined by batch sorption measurements) to describe hydrologic transport. These assumptions are:

1. microscopic equilibrium is attained between the solution species and the adsorbate,

2. only one soluble chemical species is present (or if more than one is present, they interchange rapidly),

3. the radionuclides in the solid phase are adsorbed on mineral surfaces (that is, they are not precipitated), and

4. the dependence of sorption on concentration is described by a linear isotherm.

The importance of verifying these assumptions can be demonstrated by the following hypothetical cases. If equilibrium were not attained in the batch experiments (violation of assumption 1), the retardation of radionuclides could be dependent on groundwater velocity. If a radionuclide were present in solution as an anionic and a cationic species and solution equilibrium were not maintained (violation of assumption 2), the batch measurement would predict a single retardation factor, whereas in a flowing system, the anion could move unimpeded (its size and charge excluding it from the pores of the Yucca Mountain tuff) compared to movement of the cation. If the radionuclide had precipitated in the batch experiments (violation of assumption 3), the value of the $K_{\mathrm{d}}$ thus determined would be meaningless, and depending on the precipitation mechanism, colloid transport could be important. If the isotherm was nonlinear (violation of assumption 4), the migration front of the radionuclides in a column study would usually broaden, appearing as increased dispersion over that observed for nonsorbing tracers. 


\section{EXPERIMENTAL PROCEDURES}

\section{Groundwaters}

The chemistry of groundwaters from two wells (J-13 and UE-25 p\#1) located near the repository site seems to bound that of the Yucca Mountain groundwaters (Meijer 1992), and this chemistry is summarized in Fig. 1. Both are basically sodium bicarbonate waters. Other cations are calcium, potassium, and magnesium; other anions are sulfate, chloride, nitrate, and fluoride; and the other major constituent is silica. The ionic strength of UE-25 p\#1 water is higher than that of J-13 water.
The J-13 and UE-25 p\#1 reference data plotted in Fig. 1 was obtained on site by Ogard and Kerrisk (1984). This on-site chemistry is compared with the chemistry of aliquots of J-13 and UE-25 p\#1 waters that were collected at later dates, sent to Los Alamos, and filtered. On site, the $\mathrm{pH}$ of the two groundwaters is $\sim 7$. However, at Los Alamos, the waters equilibrate in the higher-elevation atmosphere with subsequent evolution of $\mathrm{CO}_{2}$, which causes the $\mathrm{pH}$ of J-13 water to increase to 8.5 and the $\mathrm{pH}$ of UE-25 p\#1 water to increase to $\sim 9$. The data of Fig. 1 indicate that $\mathrm{CO}_{2}$ evolution and filtration does not change the chemistry of J-13 water but causes calcite precipitation in UE-25 $\mathrm{p} \# 1$

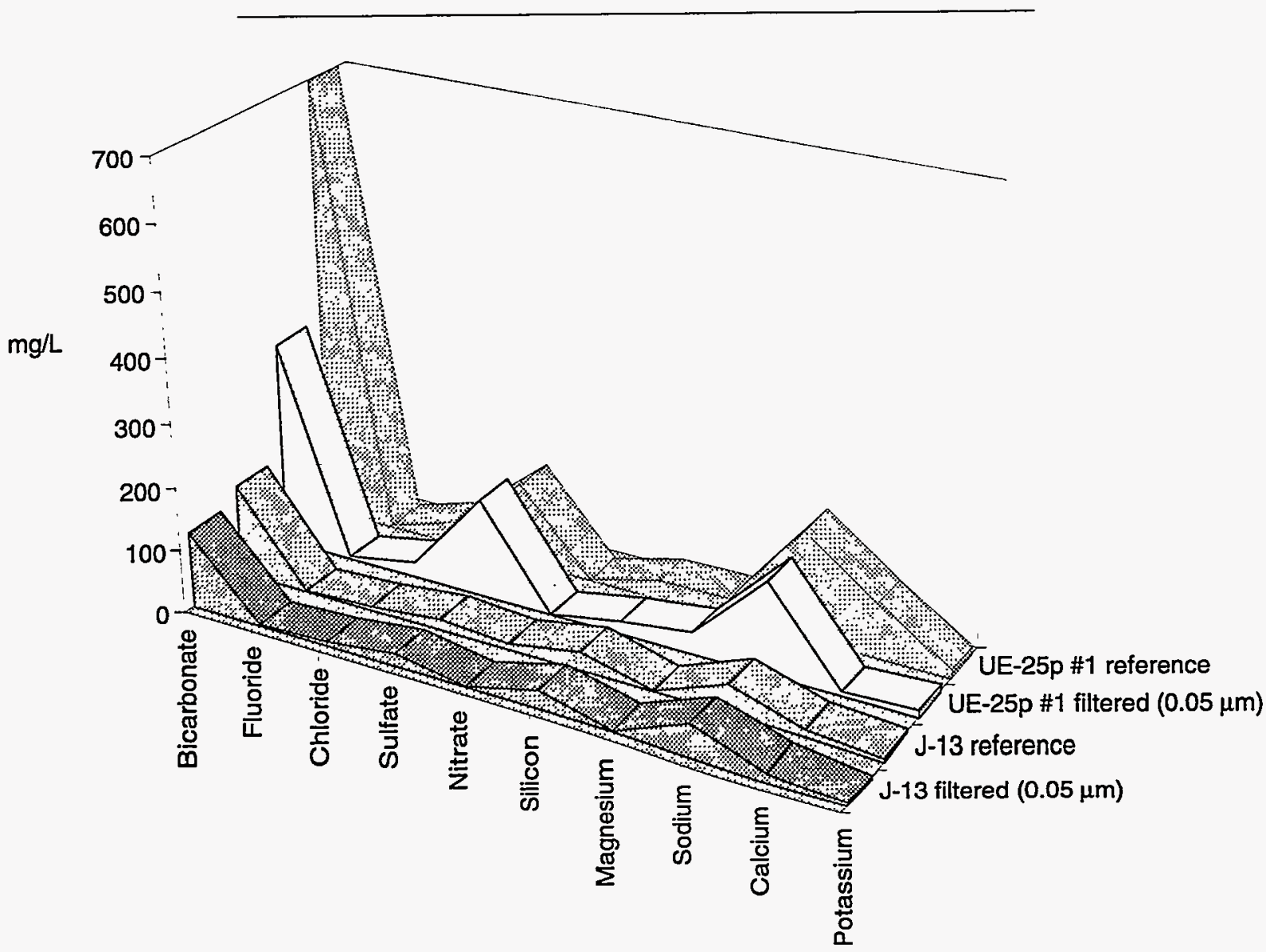

Figure 1. Chemistry of Groundwaters. The two reference samples above are water analyzed on-site in Nevada at the J-13 and UE-25 p\#1 well sites (Ogard and Kerrisk 1984). The filtered samples are water analyzed at Los Alamos, NM, after being passed through a $0.05-\mu \mathrm{m}$ filter (data recorded in binder TWS-INC-11-93-32, pages E24-E25, for J-13 and in binder TWS-INC-03-93-02, page C8, for UE-25 p\#1). The figure demonstrates the higher ionic strength of UE-25 p\#1 water, the stability of J-13 water, and the apparent calcite precipitation in UE-25 p\#1 water caused by $\mathrm{CO}_{2}$ evolution. 
water. Consequently, the concentrations of bicarbonate and calcium in any UE-25 p\#1 water used in the sorption experiments was lower than that of on-site UE-25 p\#1 water.

Because both waters are oxidizing (Ogard and Kerrisk 1984), all the batch sorption and column experiments were performed under oxidizing conditions. Both groundwaters (filtered by a $0.05-\mu \mathrm{m}$ filter) had been used in the batch sorption experiments, but in the column experiments, we used $\mathrm{J}-13$ water (filtered) and, because of the unavailability of water from Well UE-25 p\#1, a sodium bicarbonate buffer that simulated this groundwater. The synthetic UE-25 p\#1 water was prepared by dissolving $0.39 \mathrm{~g}$ of $\mathrm{Na}_{2} \mathrm{CO}_{3}$ and $8.90 \mathrm{~g}$ of $\mathrm{NaHCO}_{3}$ in 10 liters of deionized water, which duplicates the larger amount of bicarbonate in reference, or on-site, UE-25 p\#1 water.

\section{Tuff Samples}

The tuff samples we used in the batch sorption and column transport experiments were obtained from drill holes at Yucca Mountain and labeled with the drill-hole code and drill depth in feet. For example, G4-270 refers to a tuff sample taken from drill hole USW G-4 at a depth of 270 feet. The locations of the drill holes has previously been reported by Bish and Chipera (1989).

The mineralogy of the tuffs used in the sorption and transport experiments was determined by $x-$ ray-diffraction (XRD) analysis (Fig. 2), details of which were previously reported (Bish and Chipera 1989; Chipera and Bish 1989 and 1994). Prior to their use, all tuffs were crushed and wet-sieved (with the groundwater being used in the experiment) to obtain particle sizes ranging from 75 to $500 \mu \mathrm{m}$. As previously discussed by Triay et al. (1996a), such crushing and sieving does not cause significant differences in the mineralogy of the tuff samples. In several cases, it appears that sieving to eliminate particles smaller that $75 \mu \mathrm{m}$ reduces the smectite content. Because smectite is a good sorber for most radionuclides, the sieved tuff samples should yield conservative sorption results.
The three major rock types we used for sorption experiments were zeolitic, vitric, and devitrified (Fig. 2). The major component of the zeolitic tuffs is clinoptilolite; the major component of the vitric tuffs is glass; the major component of the devitrified tuffs is alkali feldspar.

\section{Neptunium Solutions}

The neptunium solutions we used for the sorption and transport experiments were prepared by taking an aliquot of a well-characterized ${ }^{237} \mathrm{~Np}(\mathrm{~V})$ acidic stock and diluting it in the water being studied. Nitsche et al. (1993 and 1994) reported the solubility and speciation of neptunium in J-13 and UE-25 p\#1 groundwaters at room temperature at $\mathrm{pH}$ values of 7 and 8.5 (Table 1 ).

\section{Batch Sorption Procedure}

We performed all batch sorption experiments at room temperature under atmospheric conditions. The procedure first involved pretreating the solid phase with the groundwater being studied ( $\mathrm{J}-13$ or UE-25 p\#1) in the ratio of $1 \mathrm{~g}$ of solid to $20 \mathrm{~mL}$ of solution. The pretreated solid phase was then separated from the groundwater by centrifugation and equilibrated with $20 \mathrm{~mL}$ of a neptunium solution (in the appropriate groundwater). After sorption, the phases were separated by centrifugation. The initial amount of ${ }^{237} \mathrm{~Np}$ in solution and the amount after sorption were determined with a liquid scintillation counter (Packard tri-carb 2550-TR/AB). The amount of ${ }^{237} \mathrm{~Np}$ in the solid phase was determined by difference. The liquid scintillation

\section{Table 1. Speciation of ${ }^{237} \mathrm{~Np}(\mathrm{~V})$ in Groundwaters*}

\begin{tabular}{|c|c|c|c|c|}
\hline Water & $\mathrm{pH}$ & Solubility (M) & $\mathrm{NpO}_{2}^{+}$ & $\mathrm{NpO}_{2} \mathrm{CO}_{3}$ \\
\hline \multirow{2}{*}{$\mathrm{J}-13$} & 7 & $1.3 \times 10^{-4}$ & $46 \%$ & $54 \%$ \\
& 8.5 & $4.4 \times 10^{-5}$ & $38 \%$ & $62 \%$ \\
& 7 & $4.7 \times 10^{-5}$ & $63 \%$ & $37 \%$ \\
UE-25 p\#1 & 8.5 & $7.0 \times 10^{-6}$ & $\mathrm{~N} / \mathrm{A}$ & $\mathrm{N} / \mathrm{A}$ \\
\hline
\end{tabular}

*From Nitsche et al. 1993 and 1994 


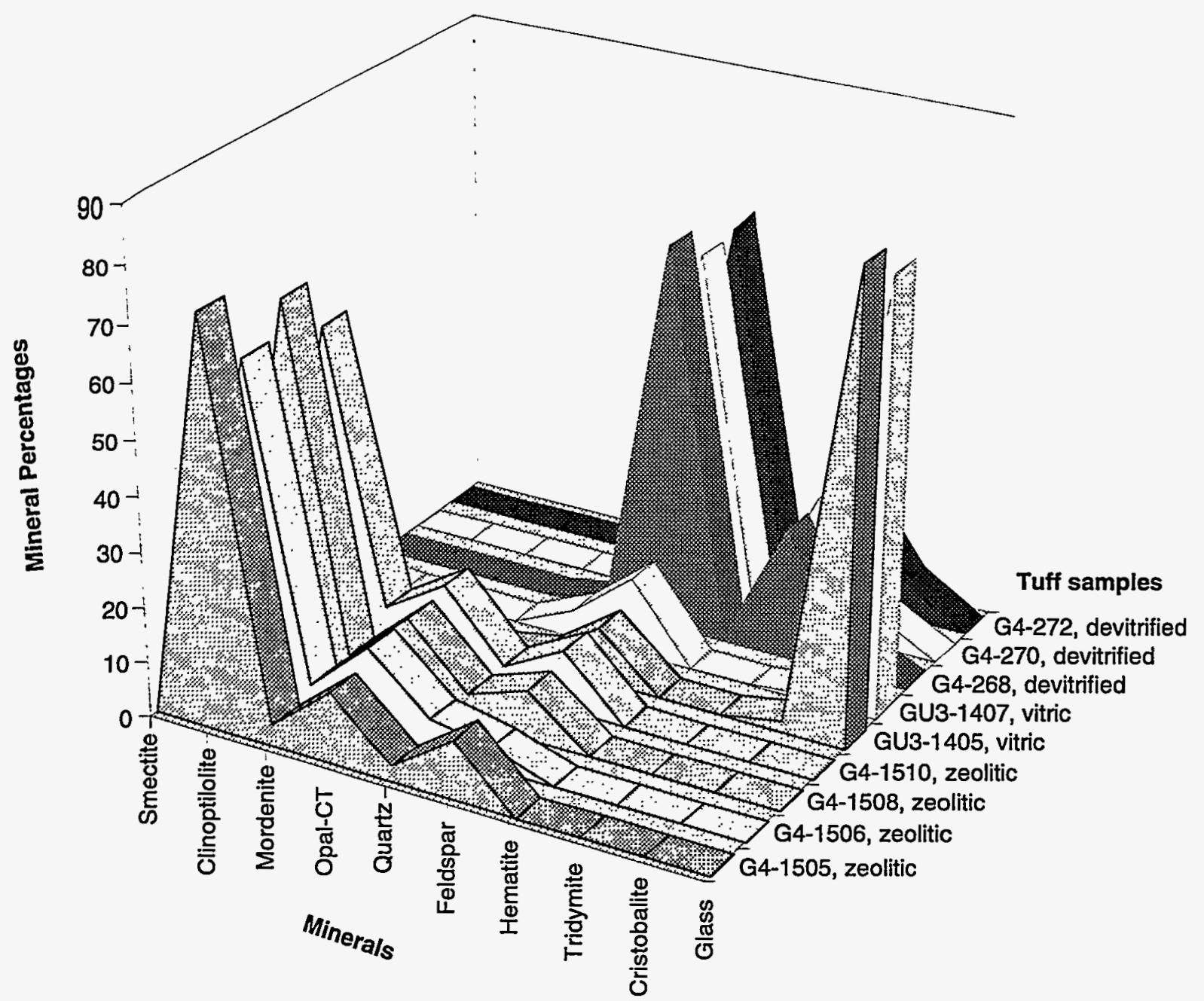

Figure 2. Tuff Mineralogies. Mineral percentages determined by $x$-ray diffraction for the tuffs used in the column experiments. Each tuff, except GU3-1405, was wet-sieved with $\mathrm{J}-13$ well water to particle sizes ranging from 75 to $500 \mu \mathrm{m}$. The data for tuffs G4-270 and G4-1506 are recorded in binder TWSINC-03-93-02; the data for all other tuffs are recorded in binder TWS-INC-11-93-32.

counting technique we used can discriminate alpha from beta activity; consequently, no interference from ${ }^{233} \mathrm{~Pa}$ (the daughter of ${ }^{237} \mathrm{~Np}$ ) is expected.

The batch sorption distribution coefficient, $K_{\mathrm{d}}$, was calculated using $K_{\mathrm{d}}=\frac{\text { moles of radionuclide per } \mathrm{g} \text { of solid phase }}{\text { moles of radionuclide per } \mathrm{mL} \text { of soln }} .[1]$ Determination of very small or very large batch sorption distribution coefficients results in large uncertainties in the values of $K_{\mathrm{d}}$ thus calculated. For example, when very little sorption occurs, the error is a result of subtracting two large numbers (the initial neptunium concentration in solution and the neptunium concentration in solution after sorption) to obtain a small number (the amount of neptunium in the solid phase).

\section{Crushed-Tuff Column Procedure}

For the column experiments, we measured the batch sorption distribution coefficients under static conditions by equilibrating a solution containing the radionuclides with a sample of crushed tuff. If we assume that equilibrium is achieved between a single aqueous chemical species and the species 
adsorbed on the solid phase, the rate at which a radionuclide moves through a column can simply be related to the sorption distribution coefficient, $K_{\mathrm{d}}$. The relationship between the retardation factor, $R_{\mathrm{f}}$ obtained from transport experiments, and the values of $K_{\mathrm{d}}$, obtained from batch sorption experiments, is generally given by

$$
R_{\mathrm{f}}=1+\frac{\rho_{\mathrm{b}}}{\varepsilon} K_{\mathrm{d}},
$$

where $\rho_{\mathrm{b}}$ is the dry bulk density and $\varepsilon$ is the porosity of the column. This equation was derived by Hiester and Vermeulen (1952), who carefully described the assumptions required for this result.

To test these assumptions, the radionuclide solution used in batch sorption measurements was eluted through columns containing tuff samples that came from the same drill hole and depth interval and that had been crushed and sieved to the same size fraction as samples used in the batch sorption studies.

We packed plexiglas columns with crushed tuff by using a continuously agitated wet slurry, a technique that provides a relatively homogeneous packing nearly free of stratification. After establishing the desired flow rate in the tuff column using the desired groundwater, we injected an aliquot of the radionuclide solution (tritiated water or ${ }^{237} \mathrm{~Np}(\mathrm{~V})$ in the appropriate groundwater) and then used a syringe pump to elute the radionuclide through the column. The breakthrough or elution curve was measured. The tritiated water was used to measure the free volume of the column, which excludes dead-end pore volume. The concentration of tritium and ${ }^{237} \mathrm{~Np}$ in the eluent was again measured by liquid scintillation counting.

The crushed-rock column dimensions and flow velocities that we used followed the guidelines provided by Relyea (1982). References describing the details of the analytical techniques and of the procedures for the batch sorption and the crushed-rock column experiments are given in Table 2 .

\section{RESULTS AND DISCUSSION}

The most comprehensive explanation of the fate of reactive and nonreactive solutes and suspended particles in porous and fractured media has been presented by de Marsily (1986). The transport of radionuclides in porous media is governed by advection, diffusion, or kinematic dispersion. Advection is the mechanism in which dissolved species are carried along by the movement of fluid. Diffusion causes species to be transferred from zones of high concentration to zones of low concentration. Kinematic dispersion is a mixing phenomenon linked to the heterogeneity of the microscopic velocities inside the porous medium. The migration of a solute in a saturated porous medium is described by the following transport equation

$$
\nabla \cdot(\mathbf{D} \nabla C-C \mathbf{U})=\varepsilon \frac{\partial C}{\partial t}+Q
$$

where $\mathbf{D}$ is the dispersion tensor, $C$ is the concentration of solute in the solution phase, $\mathbf{U}$ is the filtration velocity (Darcy's velocity), $\varepsilon$ is the porosity, $t$ is time, and $Q$ is a "net source or sink term" that accounts for such things as reactivity or adsorption.

\begin{tabular}{|c|c|}
\hline Procedure & Reference* \\
\hline Crushing and sieving & LANL-CST-DP-63 \\
\hline $\begin{array}{l}\text { Batch sorption (under } \\
\text { atmospheric conditions) }\end{array}$ & LANL-CST-DP-86 \\
\hline $\begin{array}{l}\text { Crushed-rock } \\
\text { column studies }\end{array}$ & LANL-INC-DP-15 \\
\hline $\mathrm{pH}$ measurement & LANL-CST-DP-35 \\
\hline $\begin{array}{l}\text { Liquid scintillation } \\
\text { counting }\end{array}$ & LANL-CST-DP-79 \\
\hline
\end{tabular}

Table 2. Procedures for Sorption Experiments

* Yucca Mountain Project Detailed Procedures, Los Alamos National Laboratory 
For the case of a sorbing, nonreactive solute, the equation becomes

$$
\nabla \cdot(\mathbf{D} \nabla C-C \mathbf{U})=\varepsilon \frac{\partial C}{\partial t}+\rho_{\mathrm{b}} \frac{\partial F}{\partial t}
$$

where $\rho_{\mathrm{b}}$ is the dry bulk density of the medium (including pores) and $F$ is the mass of solute sorbed per unit mass of solid.

Dispersion has three components: the longitudinal dispersion coefficient in the direction of the flow, $D_{\mathrm{L}}$, and the transverse dispersion coefficient, $D_{\mathrm{T}}$, in the two directions at right angles to the velocity of the flow. These components are given by

$$
\begin{gathered}
D_{\mathrm{L}}=\varepsilon d+\alpha_{\mathrm{L}}|U|, \text { and } \\
D_{\mathrm{T}}=\varepsilon d+\alpha_{\mathrm{T}}|U|,
\end{gathered}
$$

where $d$ is the effective diffusion coefficient in the medium and $\alpha$ is dispersivity.

The characteristics of the sorption determine the actual relationship between $F$ and $C$. For the case in which sorption is linear, reversible, and instantaneous, the ratio between $F$ and $C$ is simply equal to the sorption distribution coefficient:

$$
\frac{F}{C}=K_{\mathrm{d}}
$$

Substitution of Eqn. 6 into Eqn. 3b yields

$$
\nabla \cdot(\mathbf{D} \nabla C-C \mathrm{U})=\varepsilon\left[1+\frac{\rho_{\mathrm{b}}}{\varepsilon} K_{\mathrm{d}}\right] \frac{\partial C}{\partial t} .
$$

The expression in brackets in Eqn. 7 corresponds to the retardation factor, $R_{\mathrm{f}}$ given earlier (Eqn. 2). Thus, we have a way to compare sorption coefficients obtained under advective, diffusive, and dispersive conditions with sorption coefficients obtained from batch sorption experiments. However, this approach is valid only if sorption is linear, reversible, and instantaneous.
We measured the elution of $\mathrm{Np}(\mathrm{V})$ as a function of water velocity through zeolitic, devitrified, and vitric crushed tuff in columns with J-13 well water and with synthetic UE-25 p\#1 water. The column parameters are listed in Table 3, and the elution curves are plotted as the figures of Appendix A. The densities listed in Table 3 correspond to the dry bulk density of the columns (including pores). The porosity is the free column volume divided by the total column volume (we defined free volume as the volume of tritium solution that had to be eluted to recover $50 \%$ of the injected tritium). We then calculated values of $R_{\mathrm{f}}$ for the column experiments by dividing the free column volume into the volume of neptunium solution that had to be eluted to recover $50 \%$ of the injected ${ }^{237} \mathrm{~Np}$. From these values of $R_{f}$, we used Eqn. 2 to calculate the sorption distribution coefficients listed in Table 3.

How do the earlier results of batch sorption experiments (Triay et al.1996a and 1996b) compare with the results of the crushed-tuff column experiments? Inspection of Table 3 indicates good agreement between the values of $K_{\mathrm{d}}$ obtained by the two approaches, which means that the arrival time of ${ }^{237} \mathrm{~Np}$ can be predicted from a value for $K_{\mathrm{d}}$. On the other hand, the broad, dispersive shape of the elution curves (Appendix A) indicates that sorption of neptunium onto zeolitic and vitric tuffs does not appear to be linear, reversible, and/or instantaneous. Previous work has found that sorption of neptunium onto clinoptilolite-rich tuffs is rapid (Triay et al. 1996a) and can be fit with a linear isotherm (Triay et al. 1996b). Consequently, we will investigate the degree of reversibility of neptunium sorption onto zeolitic and vitric tuffs as the most likely reason for the apparent dispersivity in the tuff column elution curves.

Inspection of Table 3 and the elution curves also reveals that, regardless of the water being studied, the elution of ${ }^{237} \mathrm{~Np}$ does not precede the elution of tritium for any of the tuffs. This is an extremely important observation because if charge exclusion effects were to cause the neptunyl carbonato complex (an anion) to elute faster than neutral tritiated 
water molecules, significant neptunium releases could occur at Yucca Mountain. Another important observation that can be drawn from these experiments is that values of $K_{\mathrm{d}}$ can be used to obtain accurate or conservative estimates for the performance assessment calculations of neptunium transport through Yucca Mountain tuffs.

Future experiments will explore the reasons for the apparent dispersivity observed in the column experiments. To this end, the elution curves will be fitted using Eqn. 3 and a computer code (SORBEQ) that is capable of fitting elution data using sorption models other than that based on the linear isotherm generated by a $K_{\mathrm{d}}$.

\section{SUMMARY}

- Using crushed-rock columns, we studied the retardation of ${ }^{237} \mathrm{~Np}$ by zeolitic, devitrified, and vitric tuffs in sodium bicarbonate waters under oxidizing conditions (at room temperature, under atmospheric conditions, and using different water velocities).

- We compared the sorption distribution coefficients obtained from the column experiments under flowing conditions to those obtained from batch sorption experiments under static conditions.

- The column and batch distribution coefficients agreed well for all tuffs regardless of the groundwater studied and the water velocity used for the column experiments.

- We found that batch sorption distribution coefficients predict well the arrival time for neptunium eluted through a crushed-rock column.

- The apparent dispersivity of the neptunium elution curves through the zeolitic and vitric tuffs indicates that the sorption is either nonlinear, irreversible, or noninstantaneous, which means the transport cannot be completely described using a sorption distribution coefficient. The reversibility of neptunium sorption onto tuff will be studied as the most likely reason for the apparent dispersivity of the elution curves.

- The use of a batch sorption distribution coefficient to calculate neptunium transport through Yucca Mountain tuffs would result in conservative values for neptunium release.

- Neptunium never eluted prior to the nonsorbing radionuclide (tritiated water) used in the column experiments. Thus, charge exclusion does not appear to exclude neptunium from the tuff pores.

- The general trends previously observed for neptunium sorption using batch sorption experiments were corroborated by these column experiments:

a) neptunium sorption onto devitrified and vitric tuffs is minimal; and

b) neptunium sorption onto zeolitic tuffs decreases as the amount of sodium and bicarbonate/carbonate in the groundwaters increases.

\section{ACKNOWLEDGMENTS}

The authors wish to thank Dr. John Husler (from the University of New Mexico) for the chemical analysis of the groundwater used in the sorption experiments, and Mr. Phil Palmer (from Los Alamos National Laboratory) for providing the $\mathrm{Np}(\mathrm{V})$ and $\mathrm{Pu}(\mathrm{V})$ acidic stock used to prepare the sorption solutions.

The work was supported by the Yucca Mountain Site Characterization Project Office of Los Alamos National Laboratory as part of the Civilian Radioactive Waste Management Program of the 
Table 3. Neptunium Column Experimental Parameters and Comparison of $K_{\mathrm{d}}$ Values from Batch and Column Measurements*

\begin{tabular}{|c|c|c|c|c|c|c|c|c|c|c|c|c|}
\hline \multirow{3}{*}{$\begin{array}{l}\text { Column } \\
\text { Number }\end{array}$} & \multirow{3}{*}{$\begin{array}{c}\text { Tuff } \\
\text { sample } \\
\text { and type }\end{array}$} & \multicolumn{3}{|c|}{ Injected neptunium solution** } & \multicolumn{2}{|c|}{ Column parameters ${ }^{\dagger}$} & \multicolumn{3}{|c|}{ Tuff properties } & \multirow{3}{*}{$\begin{array}{c}\text { Vol. } \\
\text { flow rate } \\
\text { (mL/hr) }\end{array}$} & \multirow{2}{*}{\multicolumn{2}{|c|}{$\begin{array}{l}\text { Sorption distribution } \\
\text { coefficient, } K_{d}(\mathrm{~mL} / \mathrm{g})\end{array}$}} \\
\hline & & \multirow{2}{*}{$\begin{array}{l}\text { Water } \\
\text { type }\end{array}$} & \multirow{2}{*}{$\begin{array}{l}\text { Concentration } \\
\text { (M) }\end{array}$} & \multirow{2}{*}{$\begin{array}{c}\text { pH } \\
\text { range }\end{array}$} & \multirow{2}{*}{$\begin{array}{l}\text { Length } \\
\text { (cm) }\end{array}$} & \multirow{2}{*}{$\begin{array}{c}\text { Volume } \\
\left(\mathrm{cm}^{3}\right)\end{array}$} & \multirow{2}{*}{$\begin{array}{c}\text { Mass } \\
\text { (g) }\end{array}$} & \multirow{2}{*}{$\begin{array}{l}\text { Density } \\
\text { (g/mL) }\end{array}$} & \multirow[b]{2}{*}{ Porosity } & & & \\
\hline & & & & & & & & & & & Batch & Column \\
\hline 1 & $\begin{array}{l}\text { G4-1508 } \\
\text { zeolitic }\end{array}$ & $\mathrm{J}-13$ & $3 \times 10^{-5}$ & $8.5-8.6$ & 91.4 & 28.0 & 30.35 & 1.09 & 0.7 & 2.67 & $\begin{array}{c}1.7 \pm 0.4 \\
(\mathrm{G} 4-1510)\end{array}$ & 1.7 \\
\hline 2 & $\begin{array}{l}\text { G4-1508 } \\
\text { zeolitic }\end{array}$ & $\mathrm{J}-13$ & $3 \times 10^{-5}$ & 8.4 & 91.1 & 27.9 & 31.10 & 1.12 & 0.7 & 2.58 & $\begin{array}{c}1.7 \pm 0.4 \\
(\mathrm{G} 4-1510) \\
\end{array}$ & 1.2 \\
\hline 3 & $\begin{array}{l}\text { G4-1505 } \\
\text { zeolitic }\end{array}$ & $J-13$ & $3 \times 10^{-5}$ & $8.3-8.5$ & 91.4 & 28.0 & 31.56 & 1.13 & 0.7 & 1.72 & $2.1 \pm 0.4$ & 2.8 \\
\hline 4 & $\begin{array}{c}\text { G4-1505 } \\
\text { zeolitic }\end{array}$ & $\begin{array}{c}\text { Synthetic } \\
\text { UE-25 p\#1 }\end{array}$ & $5 \times 10^{-6}$ & $8.9-9.0$ & 91.4 & 28.0 & 29.46 & 0.95 & 0.5 & 3.10 & $\begin{array}{c}0.2 \pm 0.3 \\
(\mathrm{G} 4-1506)\end{array}$ & 0.4 \\
\hline 5 & $\begin{array}{l}\text { G4-1505 } \\
\text { zeolitic }\end{array}$ & $\begin{array}{l}\text { Synthetic } \\
\text { UE-25 p\#1 }\end{array}$ & $5 \times 10^{-6}$ & $8.9-9.0$ & 91.4 & 28.0 & 27.97 & 1.00 & 0.7 & 2.05 & $\begin{array}{c}0.2 \pm 0.3 \\
(\mathrm{G} 4-1506)\end{array}$ & 0.2 \\
\hline 6 & $\begin{array}{c}\text { G4-1505 } \\
\text { zeolitic }\end{array}$ & $\begin{array}{c}\text { Synthetic } \\
\text { UE-25 p\#1 }\end{array}$ & $5 \times 10^{-6}$ & $9.0-9.1$ & 91.4 & 28.0 & 28.91 & 0.97 & 0.7 & 0.51 & $\begin{array}{c}0.2 \pm 0.3 \\
(\mathrm{G} 4-1506)\end{array}$ & 0.2 \\
\hline 7 & $\begin{array}{c}\text { G4-268 } \\
\text { devitrified }\end{array}$ & $J-13$ & $3 \times 10^{-5}$ & 8.5 & 91.4 & 28.0 & 40.98 & 1.47 & 0.5 & 2.55 & $-0.04 \pm 0.2$ & 0.07 \\
\hline 8 & $\begin{array}{c}\text { G4-268 } \\
\text { devitrified }\end{array}$ & $\mathrm{J}-13$ & $3 \times 10^{-5}$ & $8.4-8.5$ & 91.4 & 28.0 & 40.12 & 1.43 & 0.5 & 1.78 & $-0.04 \pm 0.2$ & 0.01 \\
\hline 9 & $\begin{array}{c}\mathrm{G} 4-268 \\
\text { devitrified }\end{array}$ & $J-13$ & $3 \times 10^{-5}$ & $8.4-8.5$ & 91.4 & 28.0 & 40.21 & 1.44 & 0.5 & 1.75 & $-0.04 \pm 0.2$ & 0.02 \\
\hline 10 & $\begin{array}{c}\text { G4-268 } \\
\text { devitrified }\end{array}$ & $\mathrm{J}-13$ & $3 \times 10^{-5}$ & $8.3-8.4$ & 91.4 & 28.0 & 39.50 & 1.41 & 0.5 & 0.46 & $-0.04 \pm 0.2$ & 0.01 \\
\hline 11 & $\begin{array}{c}\text { G4-272 } \\
\text { devitrified }\end{array}$ & $\begin{array}{c}\text { Synthetic } \\
\text { UE-25 p\#1 }\end{array}$ & $5 \times 10^{-6}$ & $9.3-9.5$ & 91.1 & 27.9 & 40.80 & 1.46 & 0.5 & 3.02 & $\begin{array}{l}0.02 \pm 0.3 \\
(\mathrm{G} 4-270)\end{array}$ & 0.06 \\
\hline 12 & $\begin{array}{c}\text { G4-268 } \\
\text { devitrified }\end{array}$ & $\begin{array}{c}\text { Synthetic } \\
\text { UE-25 p\#1 }\end{array}$ & $5 \times 10^{-6}$ & $8.9-9.0$ & 91.4 & 28.0 & 36.15 & 1.29 & 0.6 & 1.75 & $\begin{array}{l}0.02 \pm 0.3 \\
(G 4-270)\end{array}$ & 0.03 \\
\hline 13 & $\begin{array}{c}\text { G4-268 } \\
\text { devitrified } \\
\end{array}$ & $\begin{array}{c}\text { Synthetic } \\
\text { UE-25 p\#1 }\end{array}$ & $5 \times 10^{-6}$ & $9.0-9.1$ & 91.1 & 27.0 & 39.96 & 1.48 & 0.5 & 0.51 & $\begin{array}{c}0.02 \pm 0.3 \\
(\mathrm{G} 4-270)\end{array}$ & 0.03 \\
\hline 14 & $\begin{array}{c}\text { GU3-1407 } \\
\text { vitric }\end{array}$ & $\mathrm{J}-13$ & $3 \times 10^{-5}$ & 8.5 & 98.9 & 30.2 & 36.66 & 1.21 & 0.5 & 2.52 & $0.1 \pm 0.5$ & 0.2 \\
\hline 15 & $\begin{array}{c}\text { GU3-1407 } \\
\text { vitric } \\
\end{array}$ & $\mathrm{J}-13$ & $3 \times 10^{-5}$ & 8.4 & 91.4 & 28.0 & 33.28 & 1.19 & 0.5 & 1.90 & $0.1 \pm 0.5$ & 0.1 \\
\hline 16 & $\begin{array}{c}\text { GU3-1405 } \\
\text { vitric }\end{array}$ & $\mathrm{J}-13$ & $3 \times 10^{-5}$ & 8.6 & 91.4 & 28.0 & 33.27 & 1.19 & 0.5 & 1.22 & $0.3 \pm 0.2$ & 0.1 \\
\hline 17 & $\begin{array}{c}\text { GU3-1405 } \\
\text { vitric }\end{array}$ & $\begin{array}{c}\text { Synthetic } \\
\text { UE-25 p\#1 }\end{array}$ & $5 \times 10^{-6}$ & 9.3 & 91.4 & 28.0 & 35.49 & 1.27 & 0.6 & 2.60 & $\begin{array}{c}0.2 \pm 0.4 \\
(\mathrm{GU} 3-1407)\end{array}$ & 0.1 \\
\hline 18 & $\begin{array}{c}\text { GU3-1405 } \\
\text { vitric } \\
\end{array}$ & $\begin{array}{c}\text { Synthetic } \\
\text { UE-25 p\#1 }\end{array}$ & $5 \times 10^{-6}$ & 9.0 & 91.4 & 28.0 & 31.50 & 1.13 & 0.6 & 1.81 & $\begin{array}{c}0.2 \pm 0.4 \\
(\mathrm{GU} 3-1407)\end{array}$ & 0.1 \\
\hline 19 & $\begin{array}{c}\text { GU3-1405 } \\
\text { vitric }\end{array}$ & $\begin{array}{l}\text { Synthetic } \\
\text { UE-25 p\#1 }\end{array}$ & $5 \times 10^{-6}$ & 8.9 & 91.4 & 28.0 & 32.19 & 1.15 & 0.6 & 1.75 & $\begin{array}{c}0.2 \pm 0.4 \\
(\mathrm{GU} 3-1407)\end{array}$ & 0.1 \\
\hline
\end{tabular}

*Tuffs were crushed and wet-sieved to particle sizes ranging from 75 to $500 \mu \mathrm{m}$. **The volume of the injected solution was $1.0 \mathrm{~mL}$ for all columns. 'The diameter of all columns was $0.6 \mathrm{~cm}$. 
U.S. Department of Energy. The Los Alamos data tracking number for this record package is LA000000000106.001.

\section{REFERENCES}

Bish, D.L., and S.J. Chipera. 1989. Revised mineralogic summary of Yucca Mountain, Nevada. Los Alamos National Laboratory report LA-11497-MS (March 1989).

Chipera, S.J., and D.L. Bish. 1989. Quantitative xray diffraction analyses of samples used for sorption studies by the Isotope and Nuclear Chemistry Division. Los Alamos National Laboratory report LA-11669-MS (September 1989).

Chipera, S.J., and D.L. Bish. 1994. Quantitative xray diffraction results for samples used for the sorption task. Letter report LA-EES-1-05-94-001, EES-1, Los Alamos National Laboratory (May 1994).

Hiester, N.K., and T. Vermeulen. 1952. Saturation performance of ion-exchange and adsorption columns. Chemical Engineering Progress 48 (No. 10): 505-516.

De Marsily, G. 1986. Quantitative Hydrogeology, Chapter 10. Academic Press, Inc.

Meijer, A. 1992. A strategy for the derivation and use of sorption coefficients in performance assessment calculations for the Yucca Mountain Site. In Proceedings of the DOE/Yucca Mountain Site Characterization Project Radionuclide Adsorption Workshop at Los Alamos National Laboratory, September 11-12, 1990, pp. 9-40. Los Alamos National Laboratory report LA-12325-C (August 1992).

Nitsche, H., R.C. Gatti, E.M. Standifer, S.C. Lee, A. Muller, T. Prussin, R.S. Deinhammer, H.

Maurer, K. Becraft, S. Leung, and S.A. Carpenter 1993. Measured solubilities and speciations of nep- tunium, plutonium, and americium in a typical groundwater (J-13) from the Yucca Mountain Region: Milestone Report 3010-WBS

1.2.3.4.1.3.1. Los Alamos National Laboratory report LA-12562-MS (July 1993).

Nitsche, H., K. Roberts, T. Prussin, A. Muller, K. Becraft, D. Keeney, S.A. Carpenter, and R.C. Gatti. 1994. Measured solubilities and speciations from oversaturation experiments of neptunium, plutonium, and americium in UE-25 p\#1 Well from the Yucca Mountain Region: Milestone Report 3329-WBS 1.2.3.4.1.3.1. Los Alamos National Laboratory report LA-12563-MS (April 1994).

Ogard, A.E., and J.F. Kerrisk. 1984. Groundwater chemistry along flow paths between a proposed repository site and the accessible environment. Los Alamos National Laboratory report LA-10188MS (November 1984).

Relyea, J.F. 1982. Theoretical and experimental considerations for the use of the column method for determining retardation factors. Radioactive Waste Management and the Nuclear Fuel Cycle 3 (No. 2): 151-166.

Thomas, K.W. 1987. Summary of sorption measurements performed with Yucca Mountain, Nevada, tuff samples and water from Well J-13. Los Alamos National Laboratory report LA-10960MS.

Triay I.R., C.R. Cotter, M.H. Huddleston, D.E. Leonard, S.C. Weaver, S.J. Chipera, D.L. Bish, A. Meijer, and J.A. Canepa. 1996a. Batch sorption results for neptunium transport through Yucca Mountain tuffs. Los Alamos National Laboratory report LA-12961-MS.

Triay, I.R., C.R. Cotter, S.M. Kraus, M.H. Huddleston, S.J. Chipera, and D.L. Bish. 1996b. Radionuclide sorption in Yucca Mountain tuffs with J-13 well water: neptunium, uranium, and plutonium. Los Alamos National Laboratory report LA-12956-MS. 
APPENDIX A: NEPTUNIUM COLUMN ELUTION CURVES 


\section{APPENDIX A: NEPTUNIUM COLUMN ELUTION CURVES}

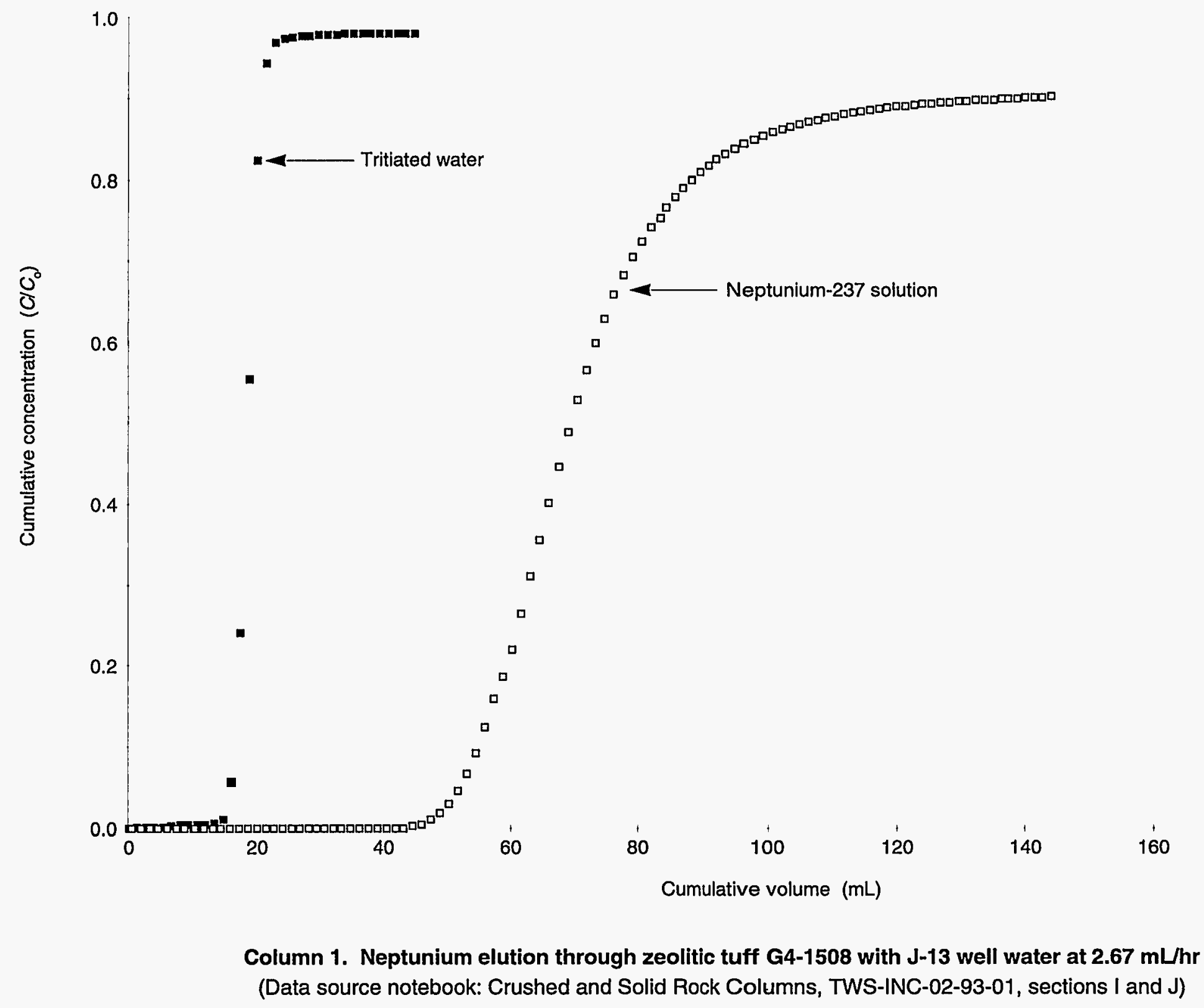




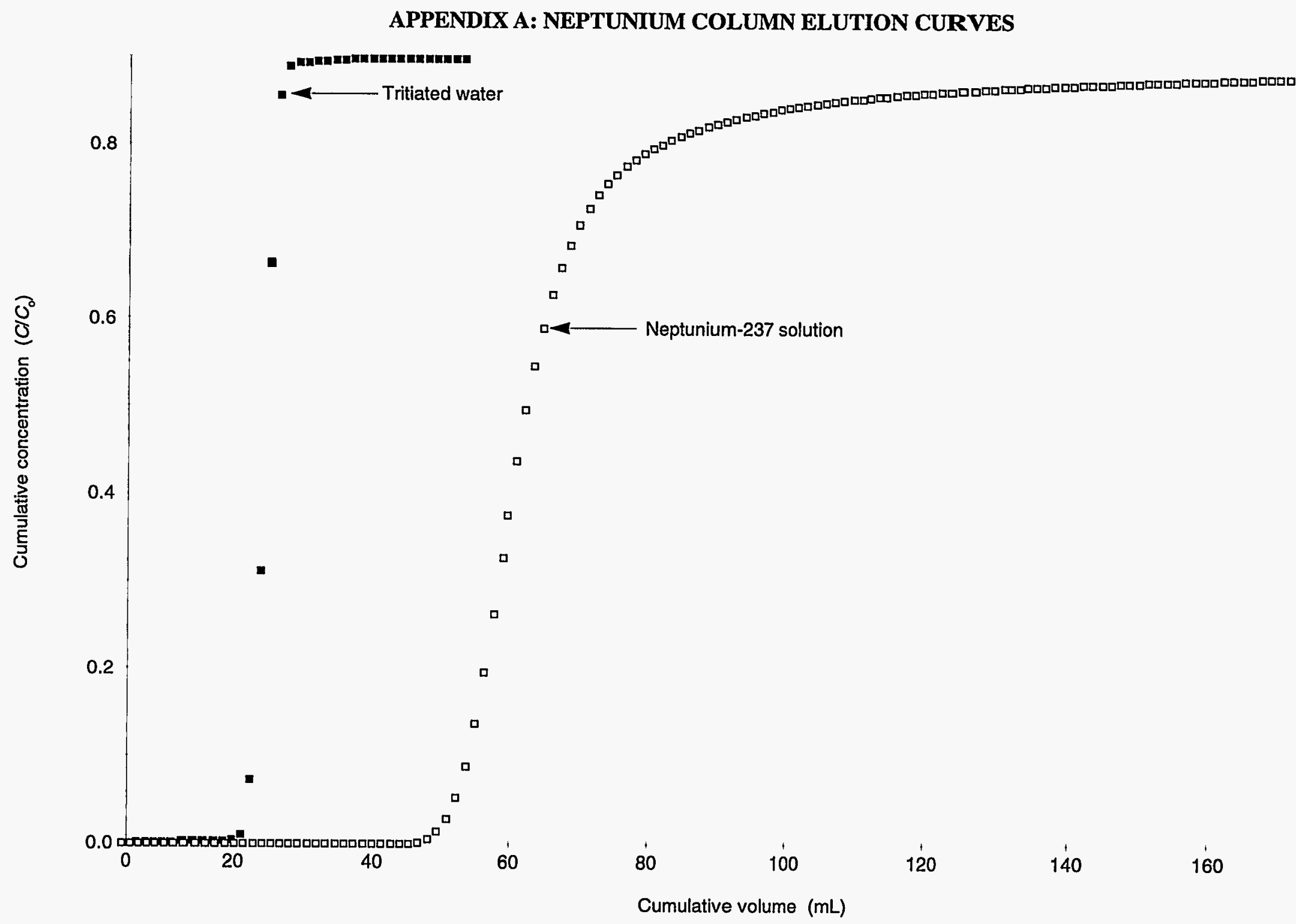

Column 2. Neptunium elution through zeolitic tuff G4-1508 with $\mathrm{J}-13$ well water at $2.58 \mathrm{~mL} / \mathrm{hr}$ (Data source notebook: Crushed and Solid Rock Columns, TWS-INC-02-93-01, sections K and L) 


\section{APPENDIX A: NEPTUNIUM COLUMN ELUTION CURVES}

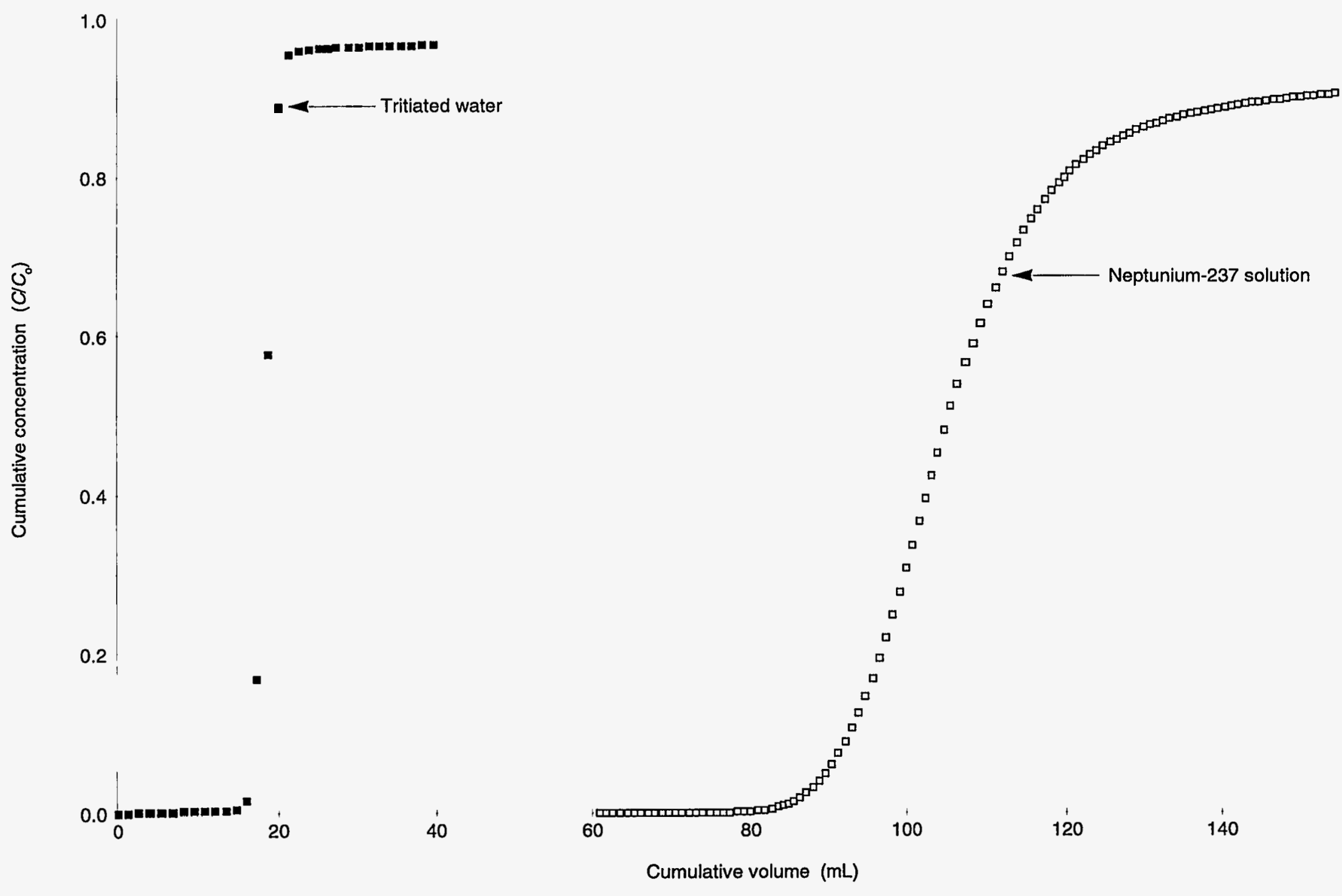

Column 3. Neptunium elution through zeolitic tuff G4-1505 with J-13 well water at $1.72 \mathrm{~mL} / \mathrm{hr}$ (Data source notebook: Crushed and Solid Rock Columns, TWS-INC-02-93-01, section S) 
APPENDIX A: NEPTUNIUM COLUMN ELUTION CURVES

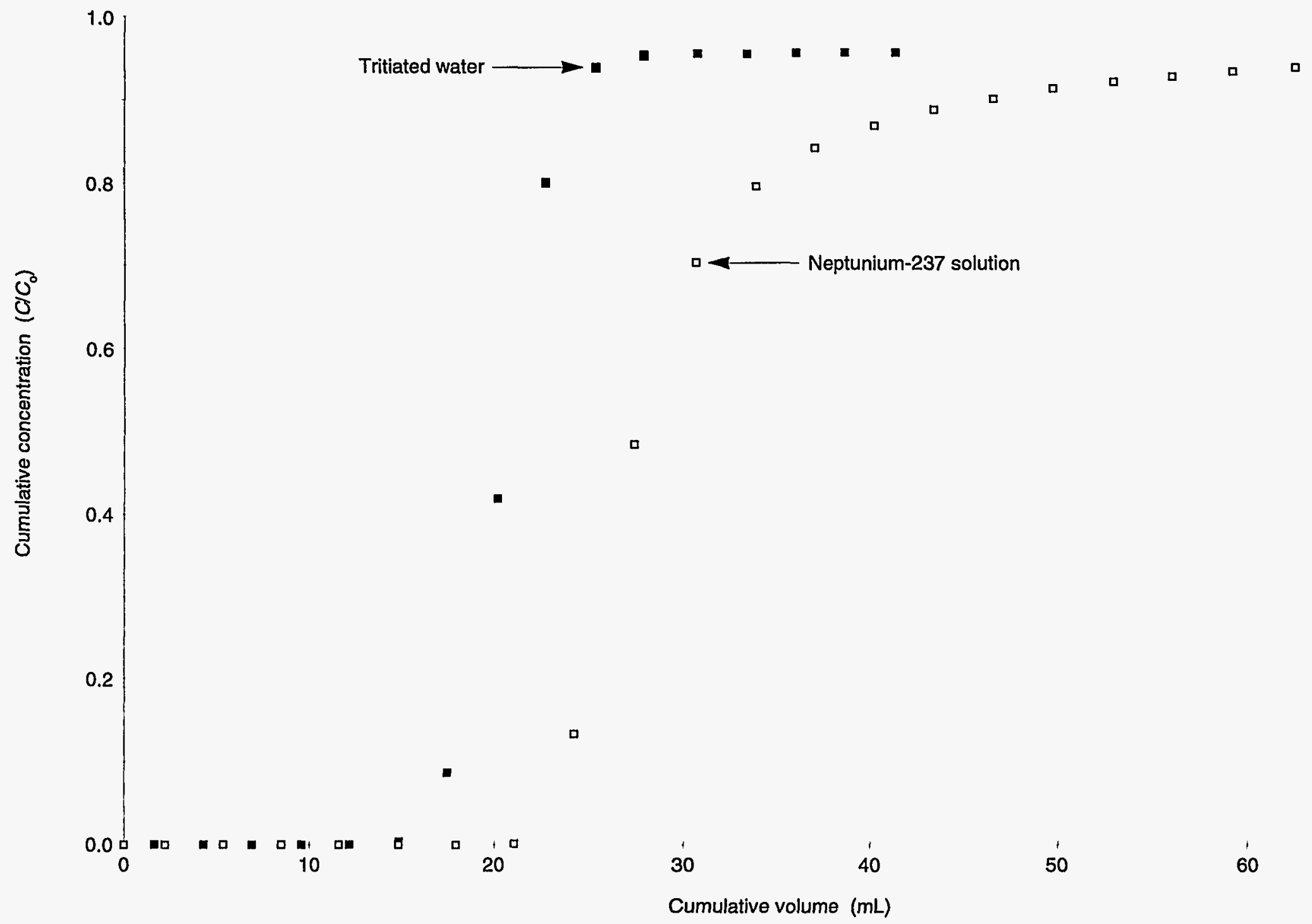

Column 4. Neptunium elution through zeolitic tuff G4-1505 with synthetic UE-25 p\#1 water at 3.10 mL/hr (Data source notebook: Crushed and Solid Rock Columns, TWS-INC-02-93-01, section X) 


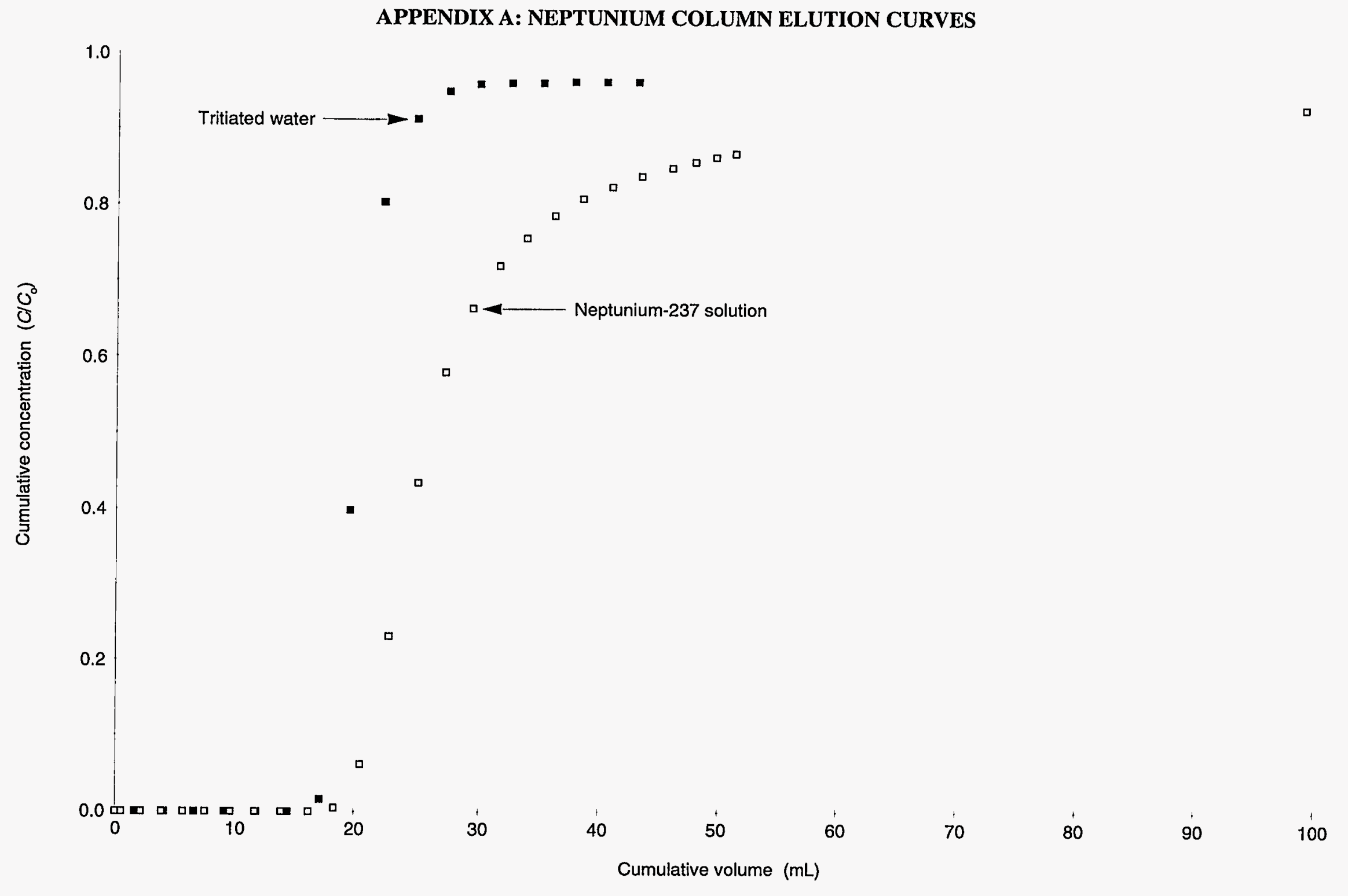

Column 5. Neptunium elution through zeolitic tuff G4-1505 with synthetic UE-25 p\#1 water at $2.05 \mathrm{~mL} / \mathrm{hr}$ (Data source notebook: Crushed and Solid Rock Columns, TWS-INC-02-93-01, section Z) 


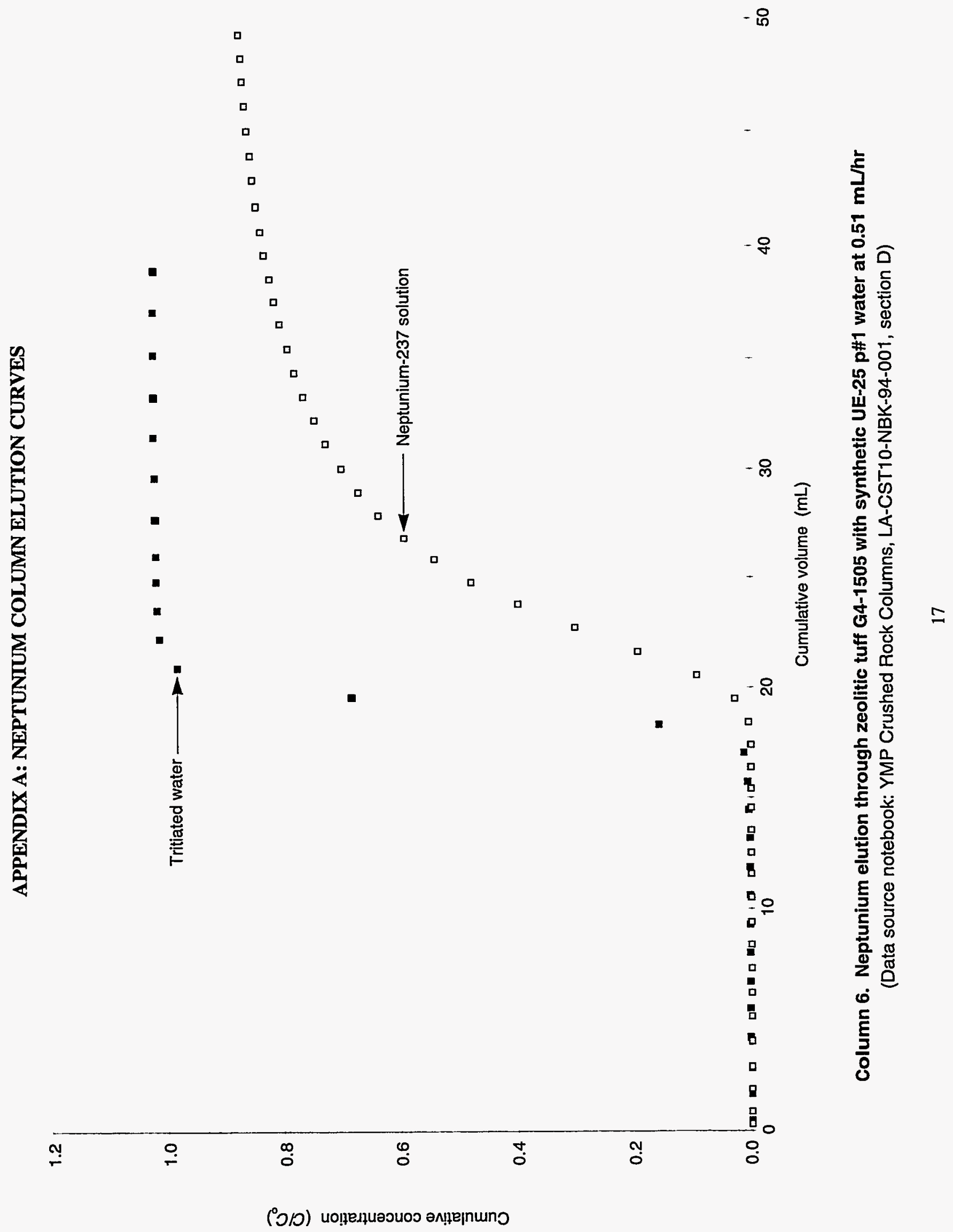




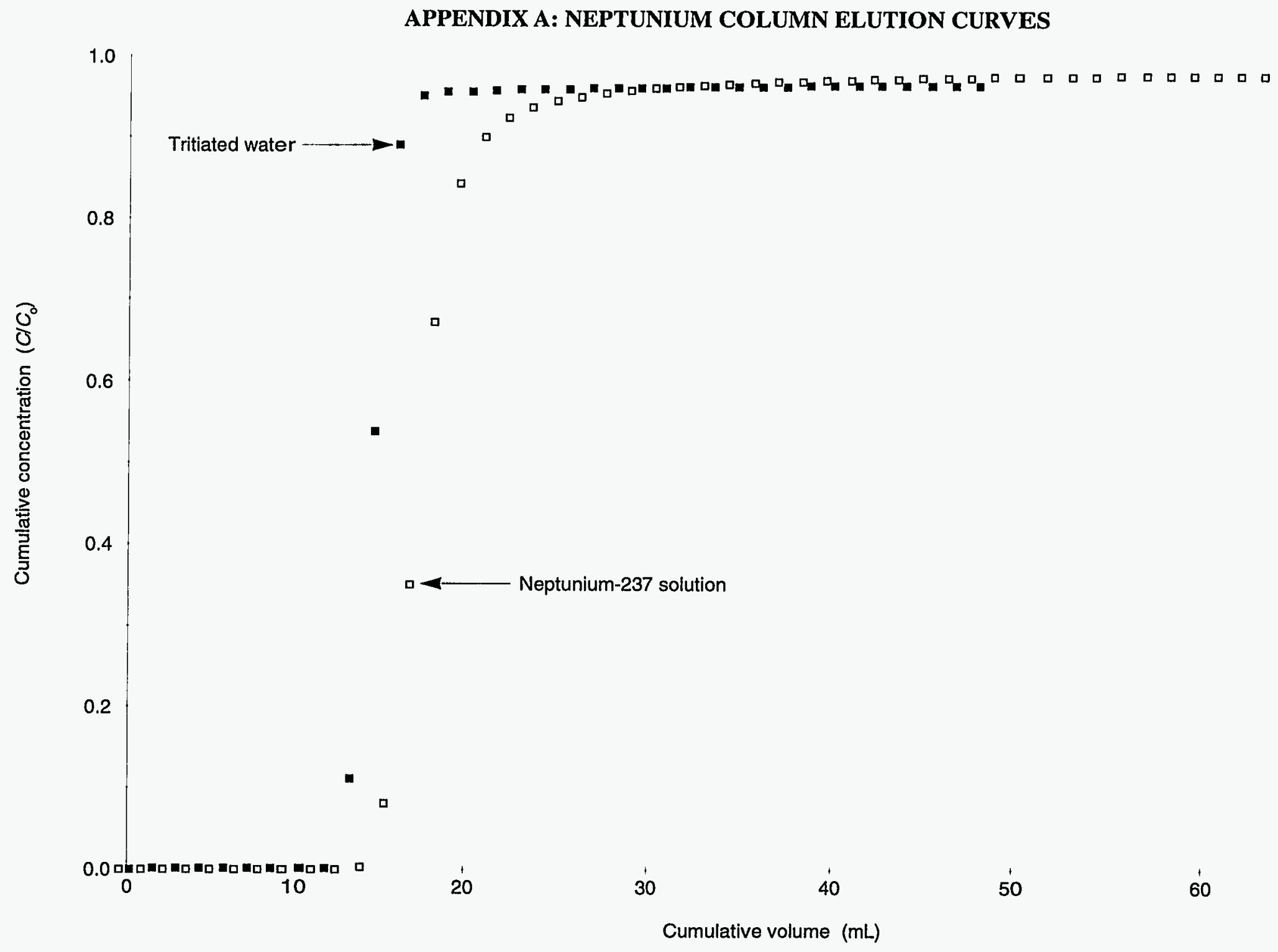

Column 7. Neptunium elution through devitrified tuff G4-268 with J-13 well water at $2.55 \mathrm{~mL} / \mathrm{hr}$ (Data source notebook: Crushed and Solid Rock Columns, TWS-INC-02-93-01, sections M and N) 


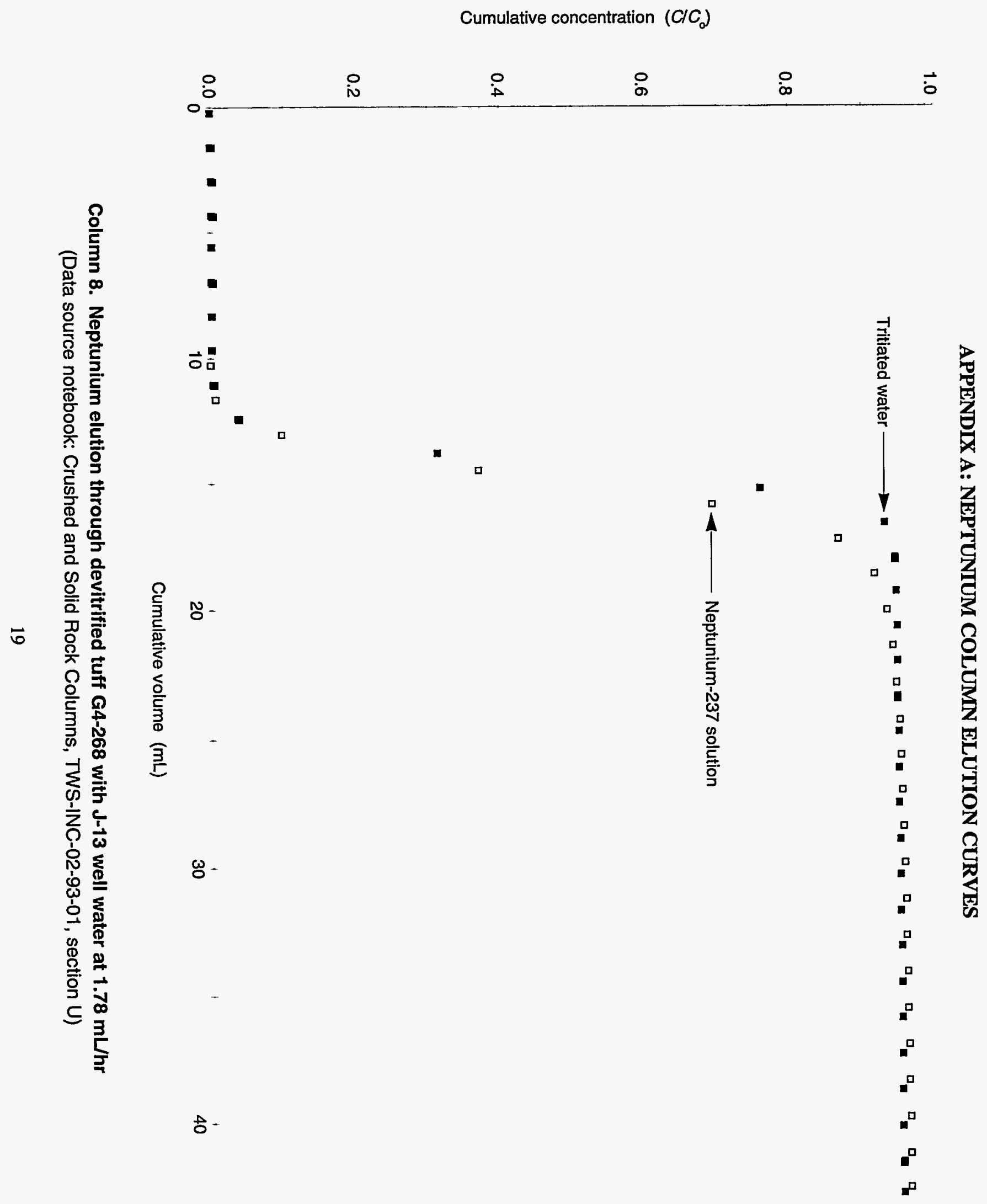




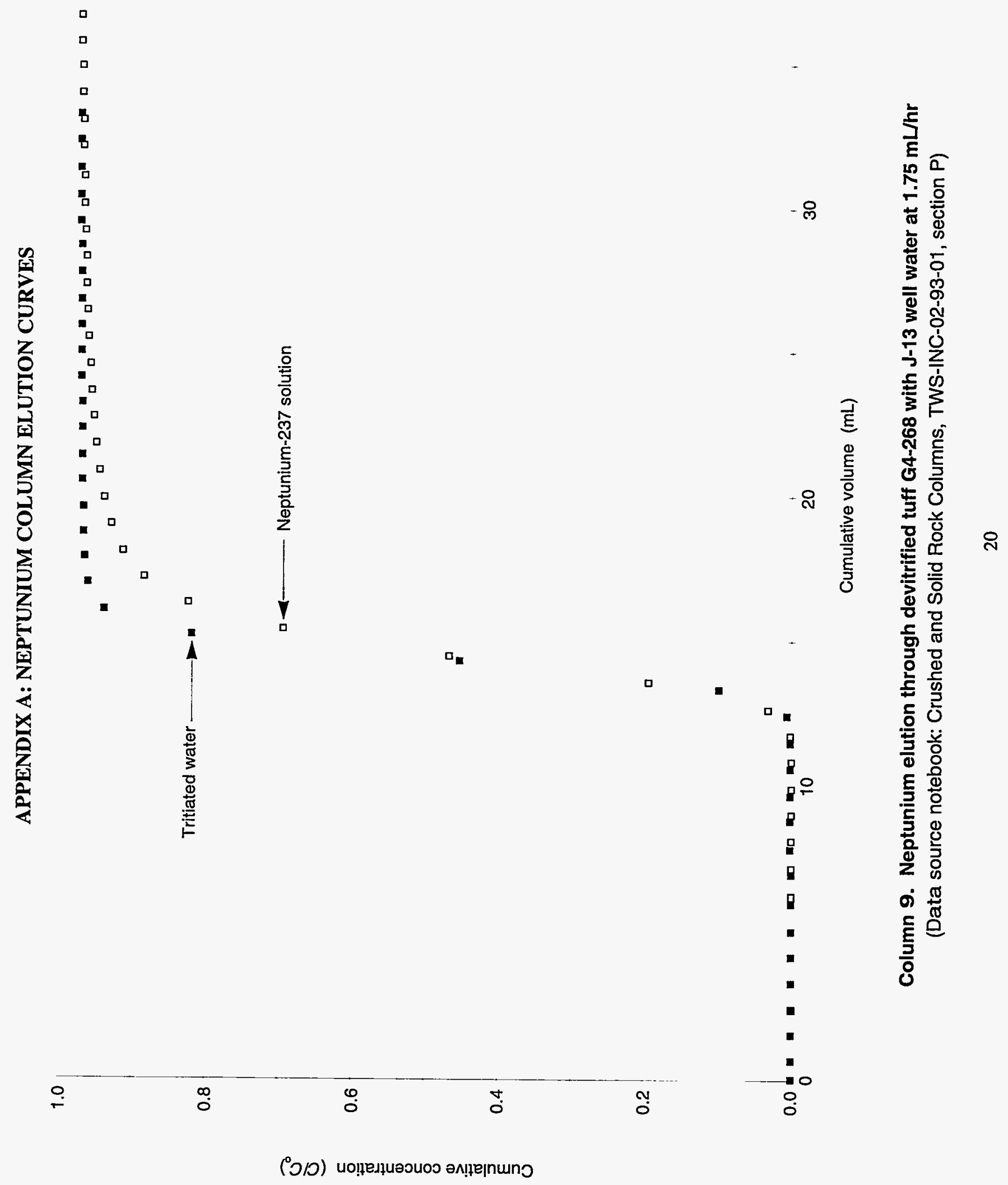




\section{APPENDIX A: NEPTUNIUM COLUMN ELUTION CURVES}

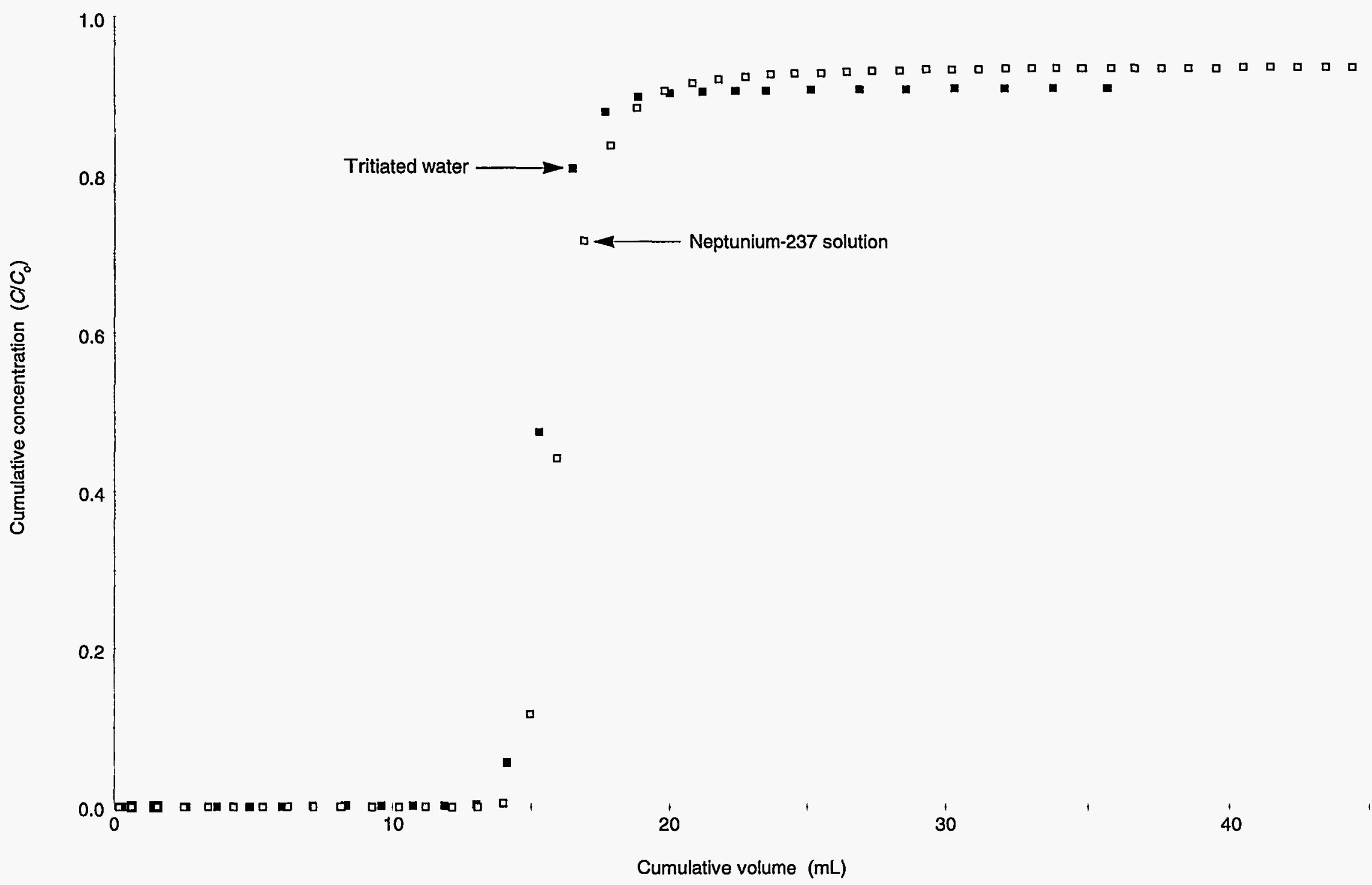

Column 10. Neptunium elution through devitrified tuff G4-268 with J-13 well water at $0.46 \mathrm{~mL} / \mathrm{hr}$ (Data source notebook: YMP Crushed Rock Columns, LA-CST10-NBK-94-001, section C) 


\section{APPENDIX A: NEPTUNIUM COLUMN ELUTION CURVES}

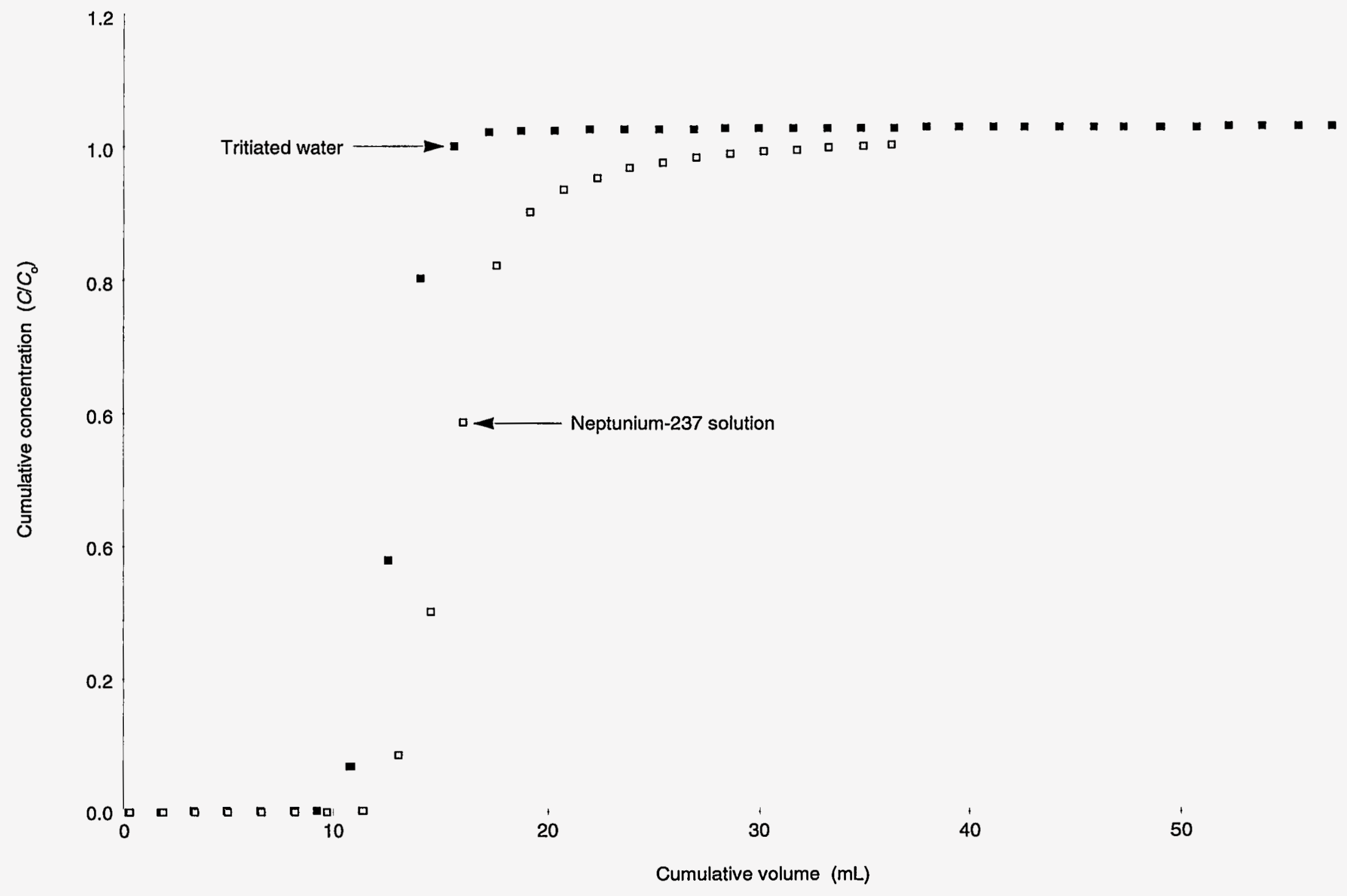

Column 11. Neptunium elution through devitrified tuff G4-272 with synthetic UE-25 p\#1 water at $3.02 \mathrm{~mL} / \mathrm{hr}$ (Data source notebook: Crushed and Solid Rock Columns, TWS-INC-02-93-01, section R) 

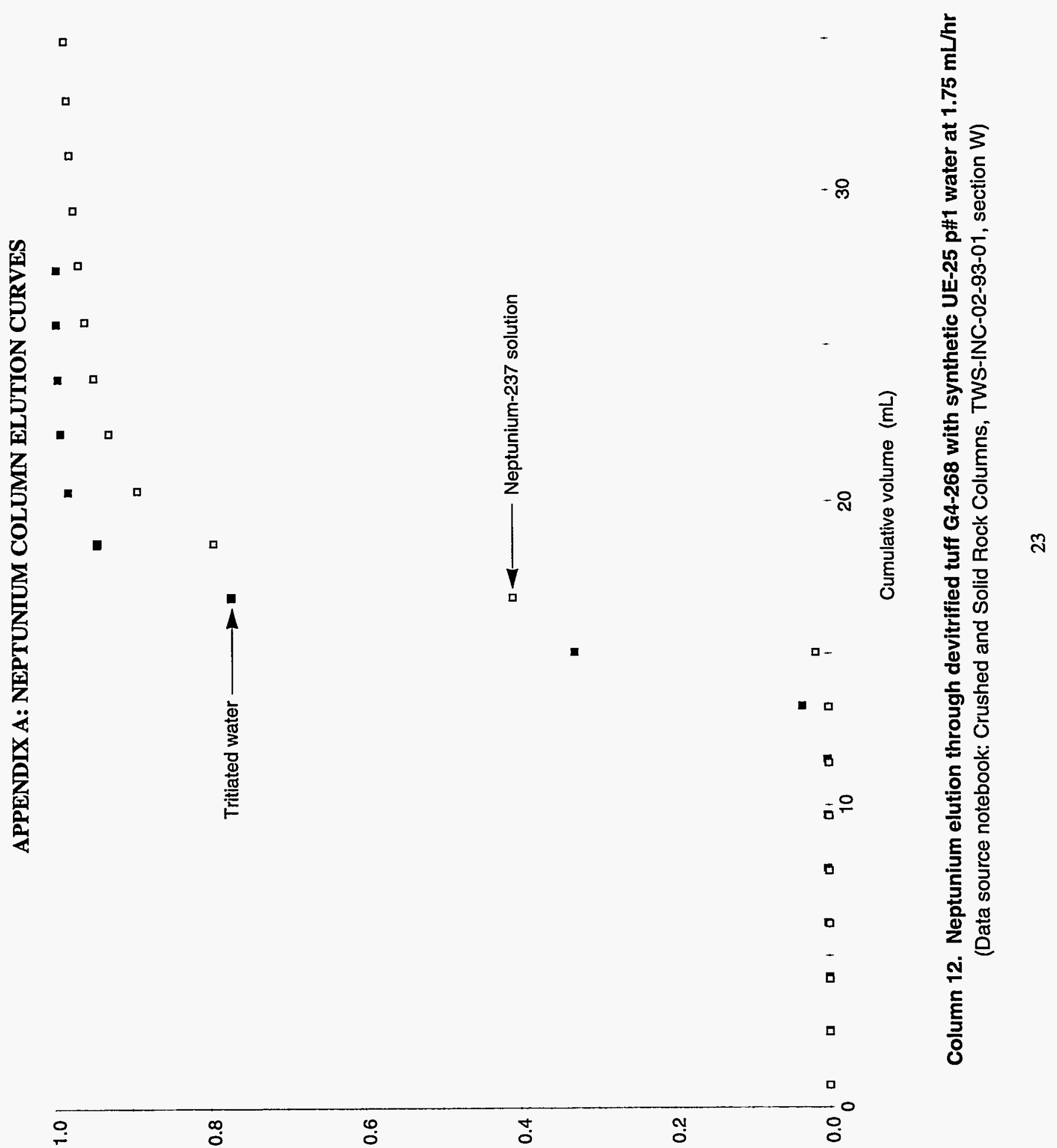

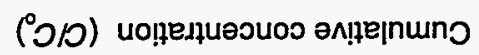




\section{APPENDIX A: NEPTUNIUM COLUMN ELUTION CURVES}

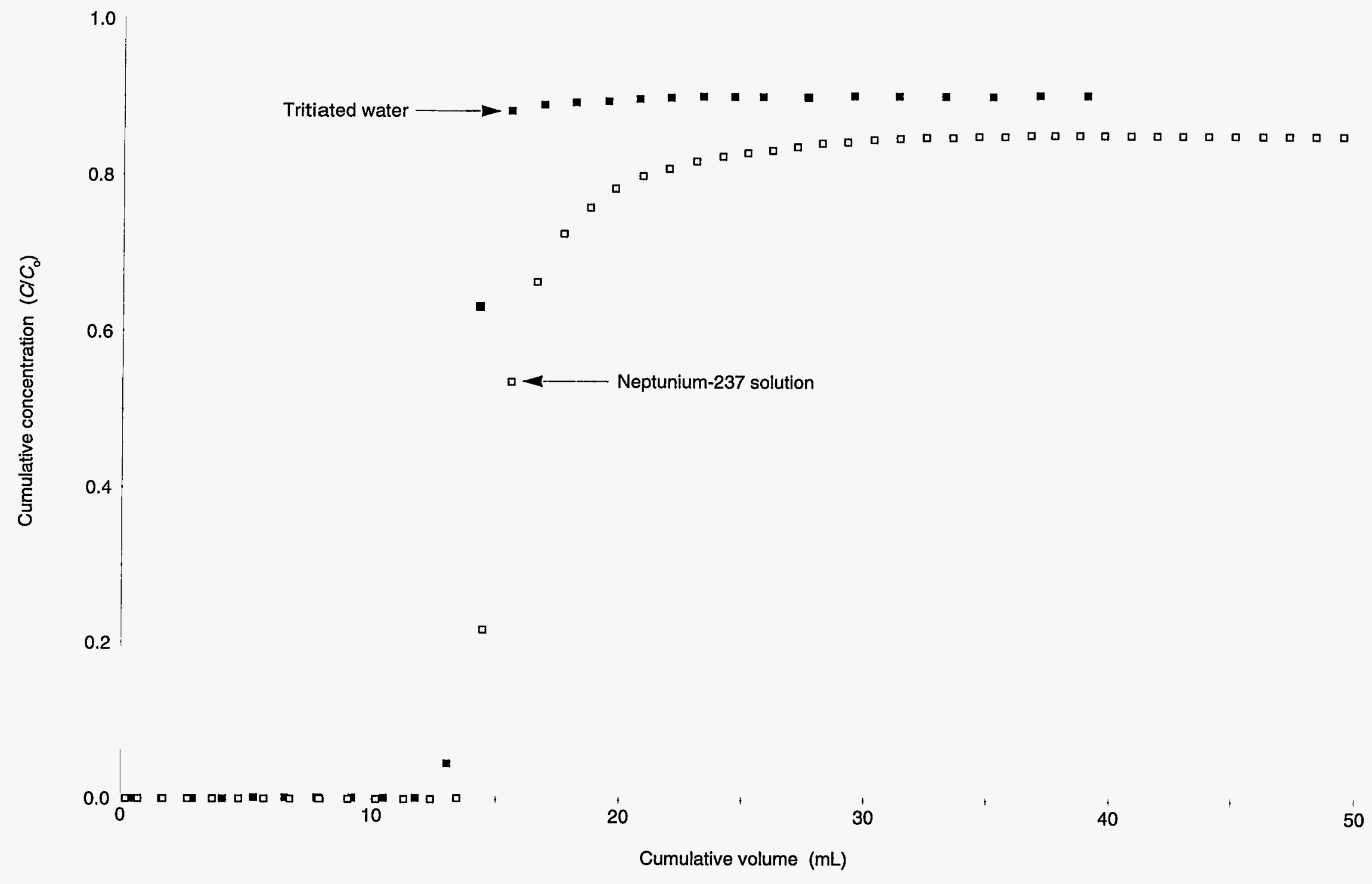

Column 13. Neptunium elution through devitrified tuff G4-268 with synthetic UE-25 p\#1 water at $0.51 \mathrm{~mL} / \mathrm{hr}$ (Data source notebook: YMP Crushed Rock Columns, LA-CST10-NBK-94-001, section C) 


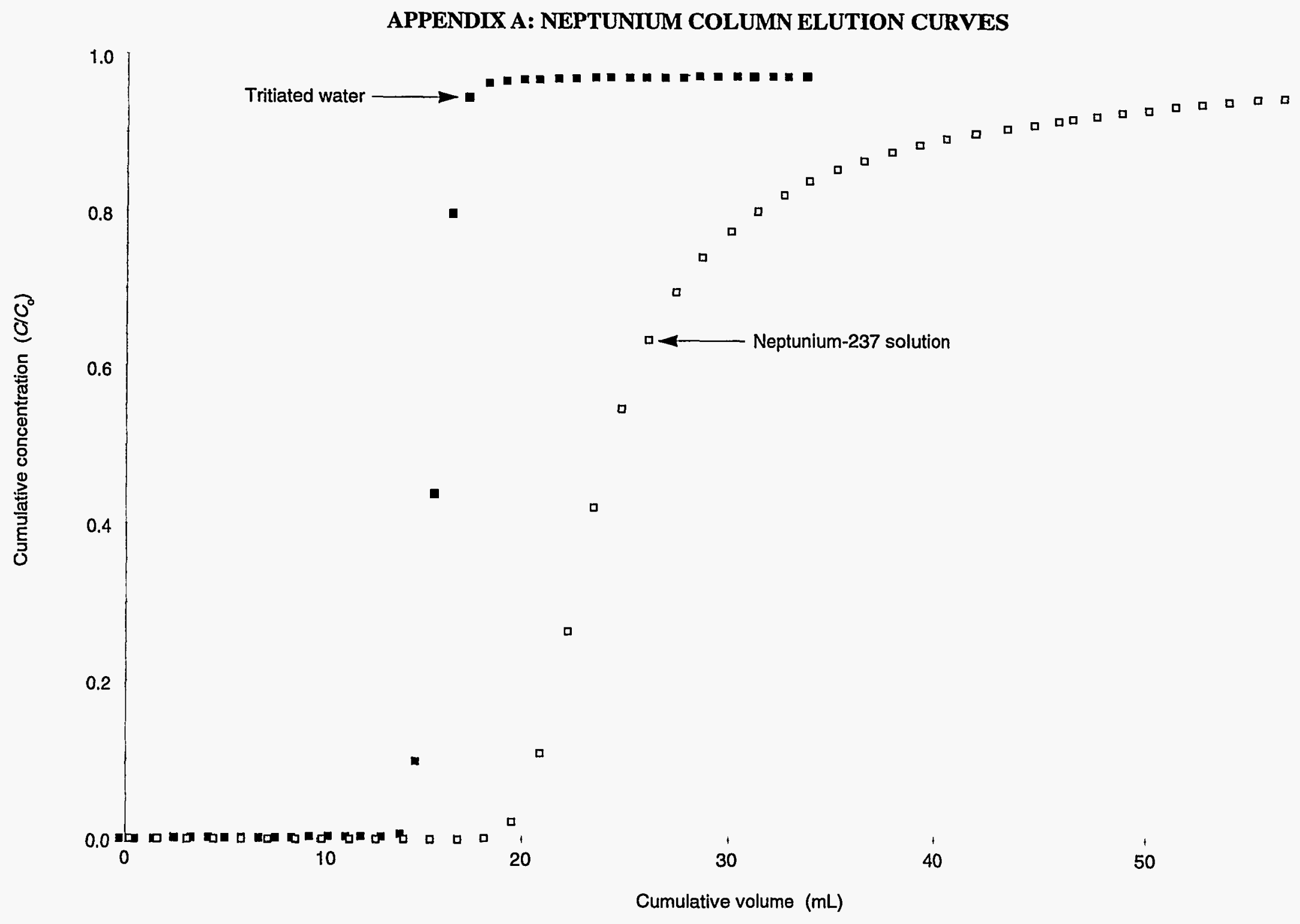

Column 14. Neptunium elution through vitric tuff GU3-1407 with J-13 well water at $2.52 \mathrm{~mL} / \mathrm{hr}$ (Data source notebook: Crushed and Solid Rock Columns, TWS-INC-02-93-01, section W) 
口

口

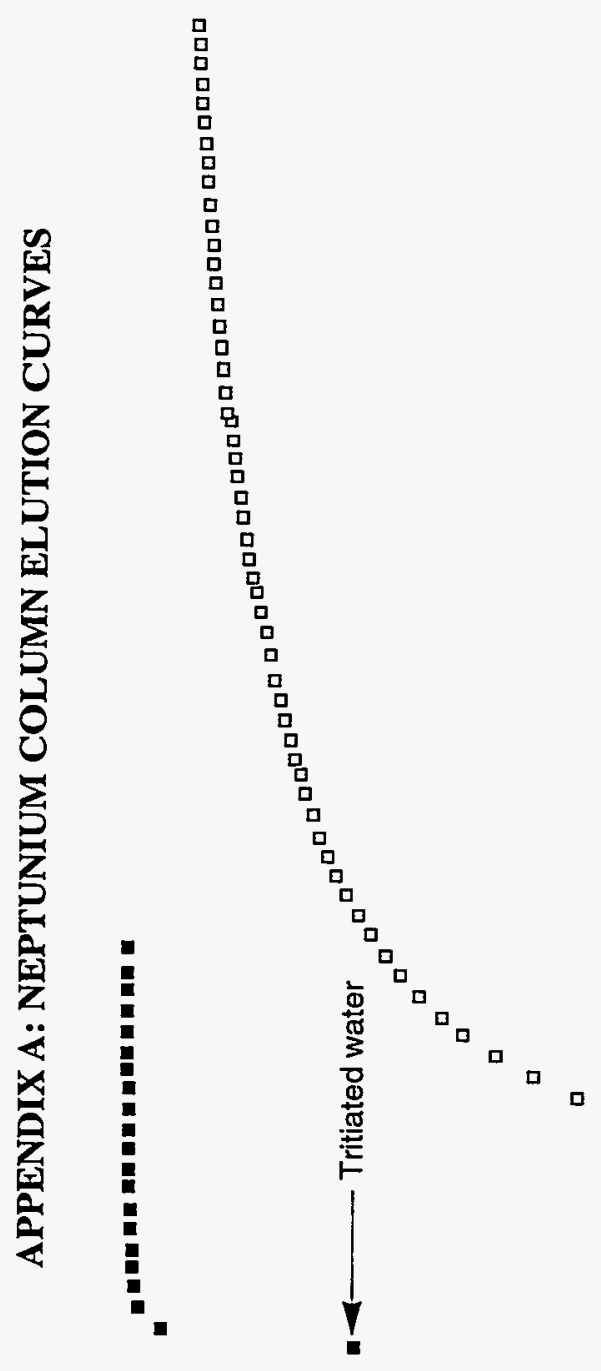

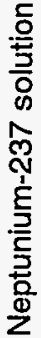

8

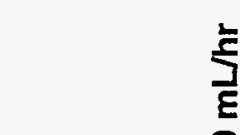<smiles>[Li]</smiles>
$\widehat{0}$
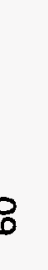

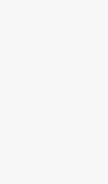

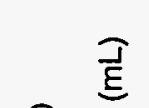

छิ

$-80$

- 으

ㅁ
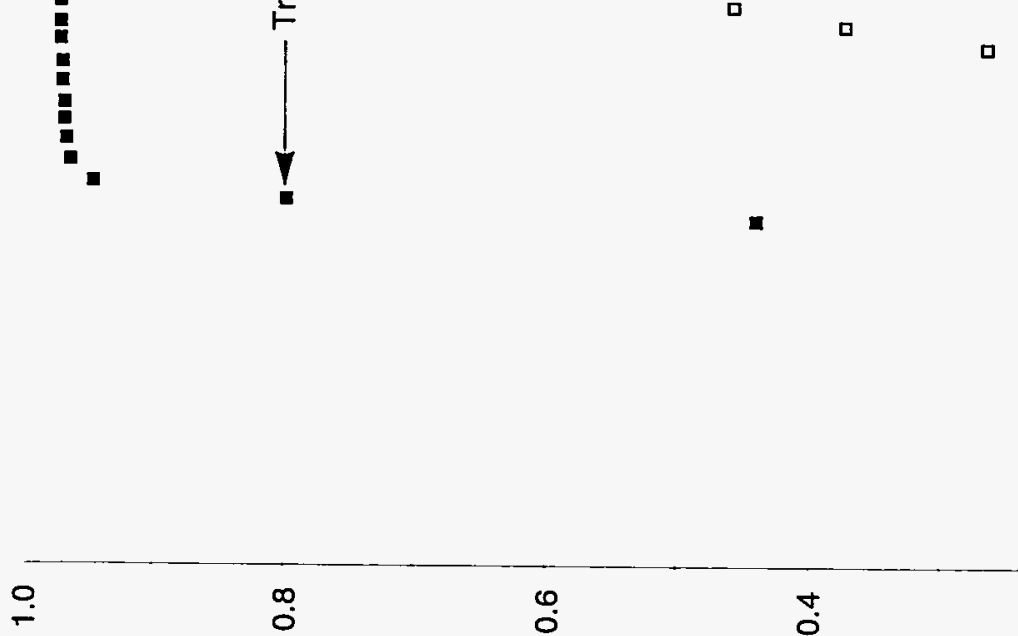

\%
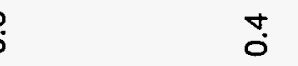

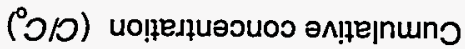




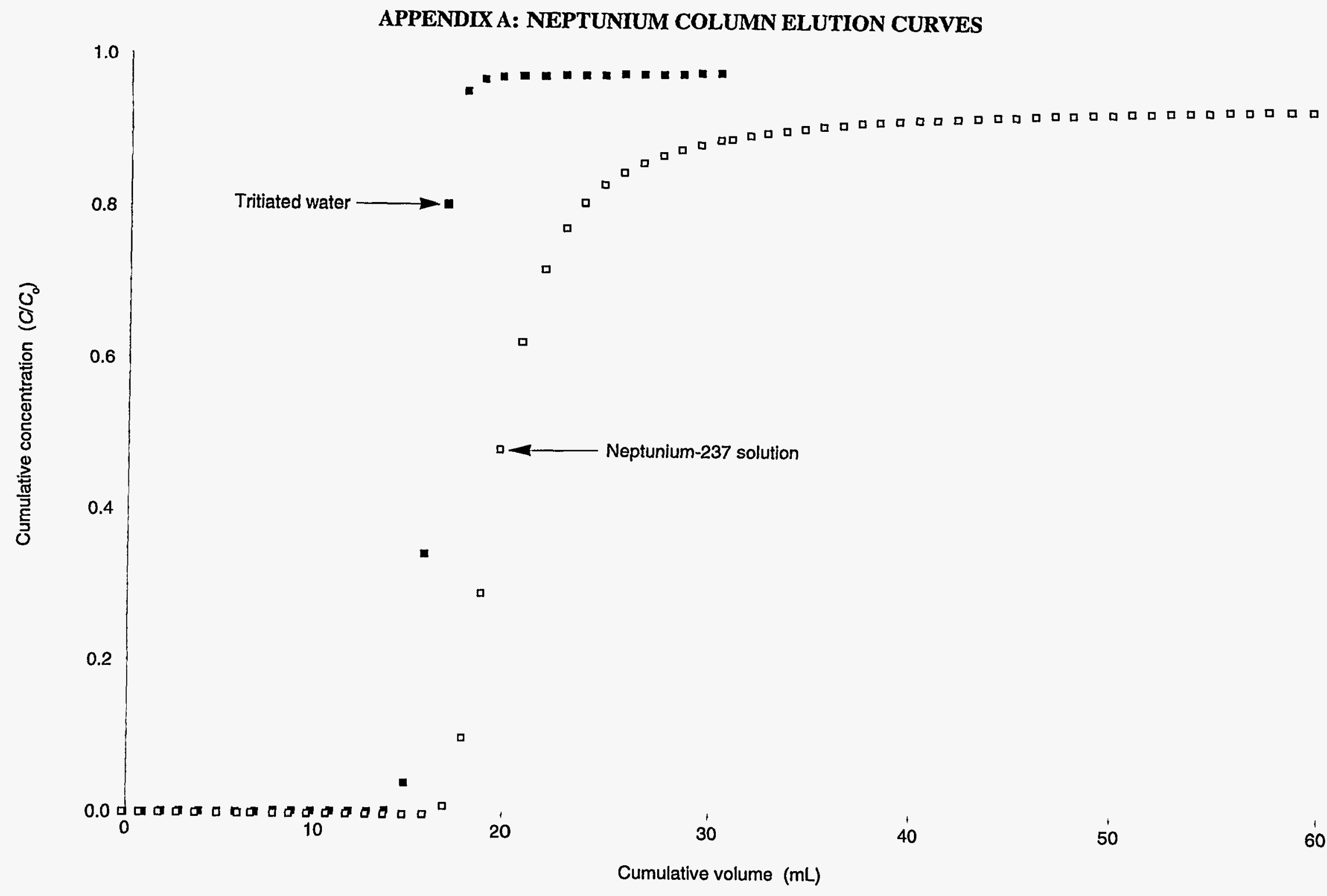

Column 16. Neptunium elution through vitric tuff GU3-1405 with J-13 well water at $1.22 \mathrm{~mL} / \mathrm{hr}$

(Data source notebook: Crushed and Solid Rock Columns, TWS-INC-02-93-01, section V) 


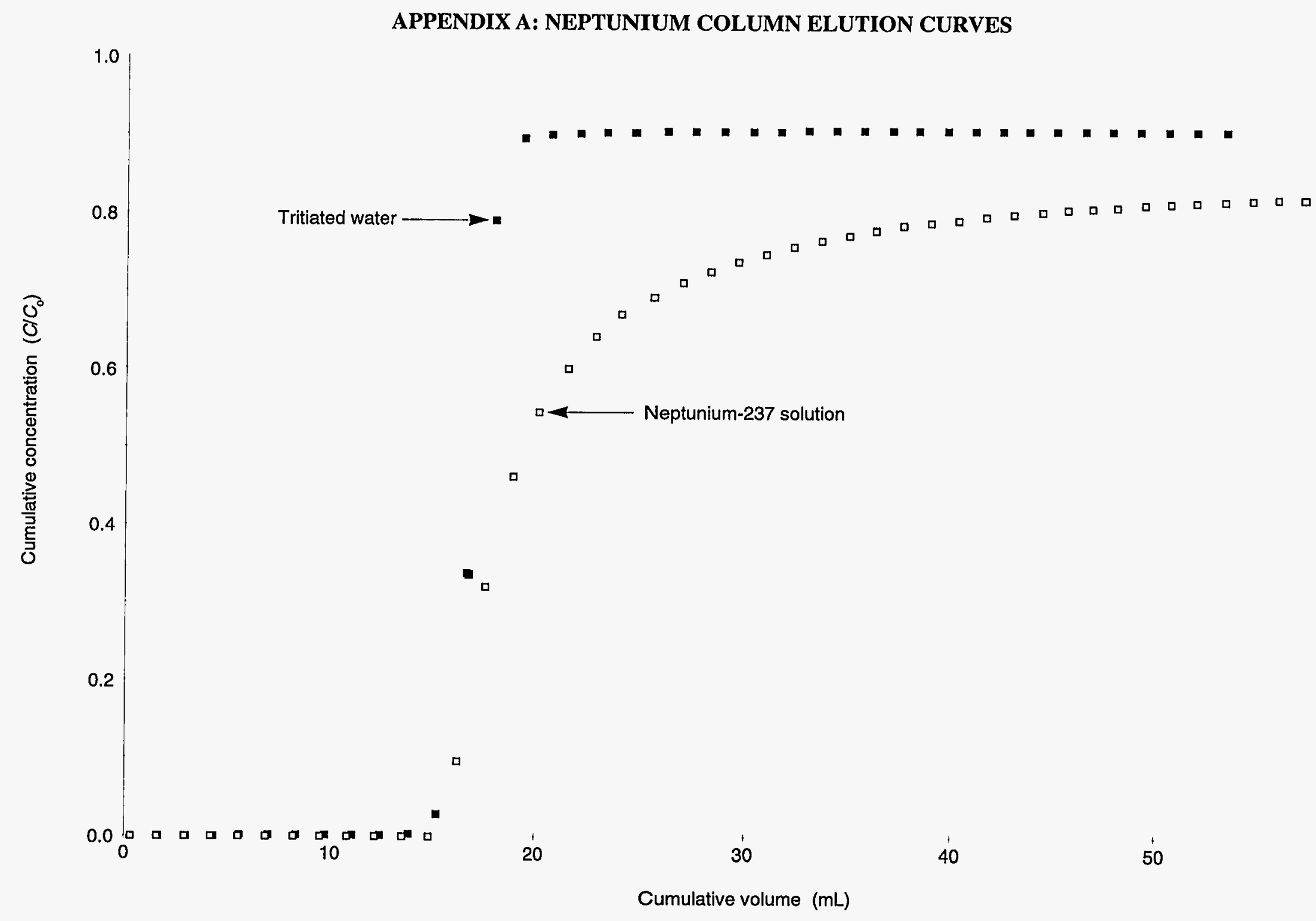

60

Column 17. Neptunium elution through vitric tuff GU3-1405 with synthetic UE-25 p\#1 water at $2.60 \mathrm{~mL} / \mathrm{hr}$ (Data source notebook: Crushed and Solid Rock Columns, TWS-INC-02-93-01, section T) 


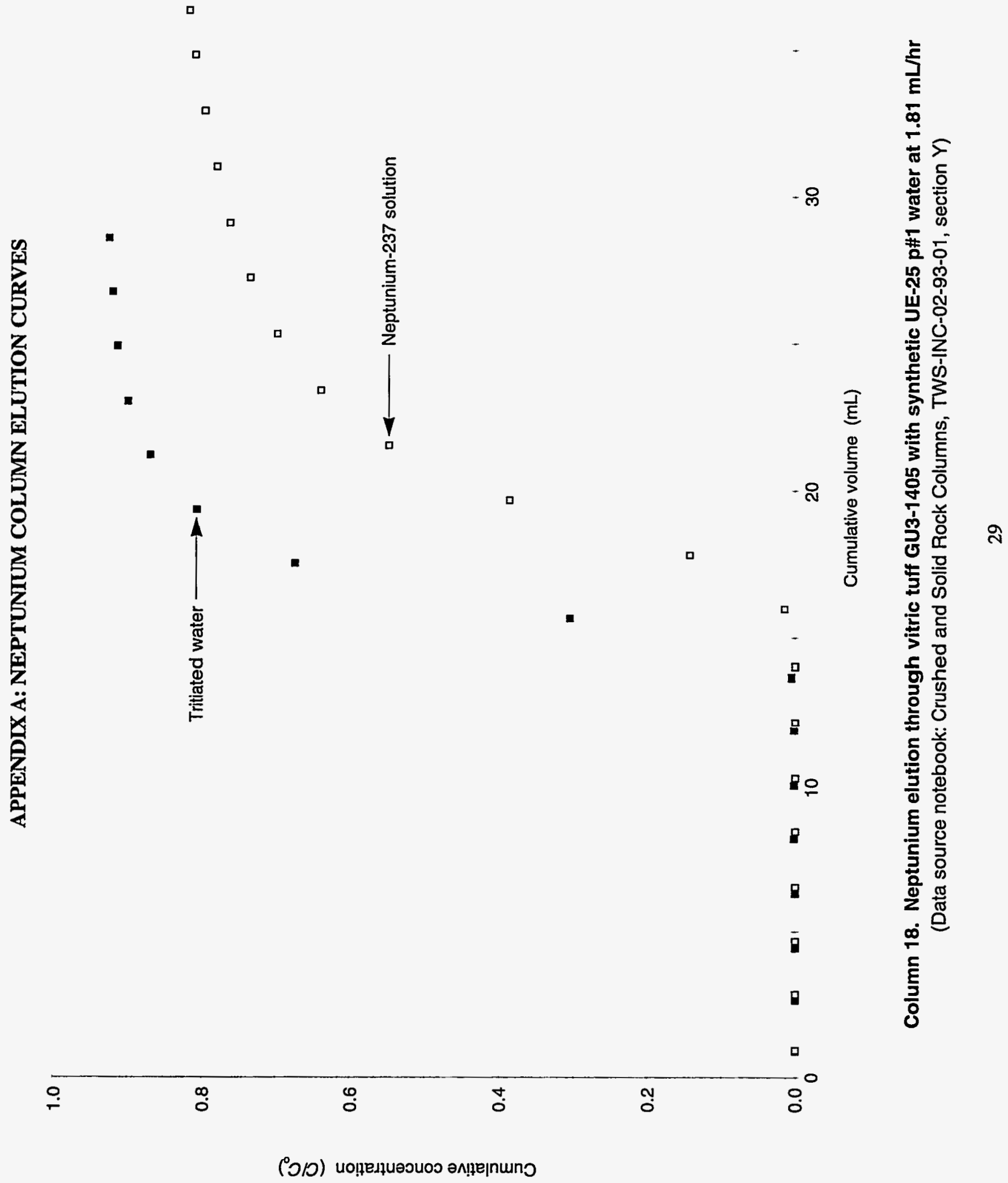




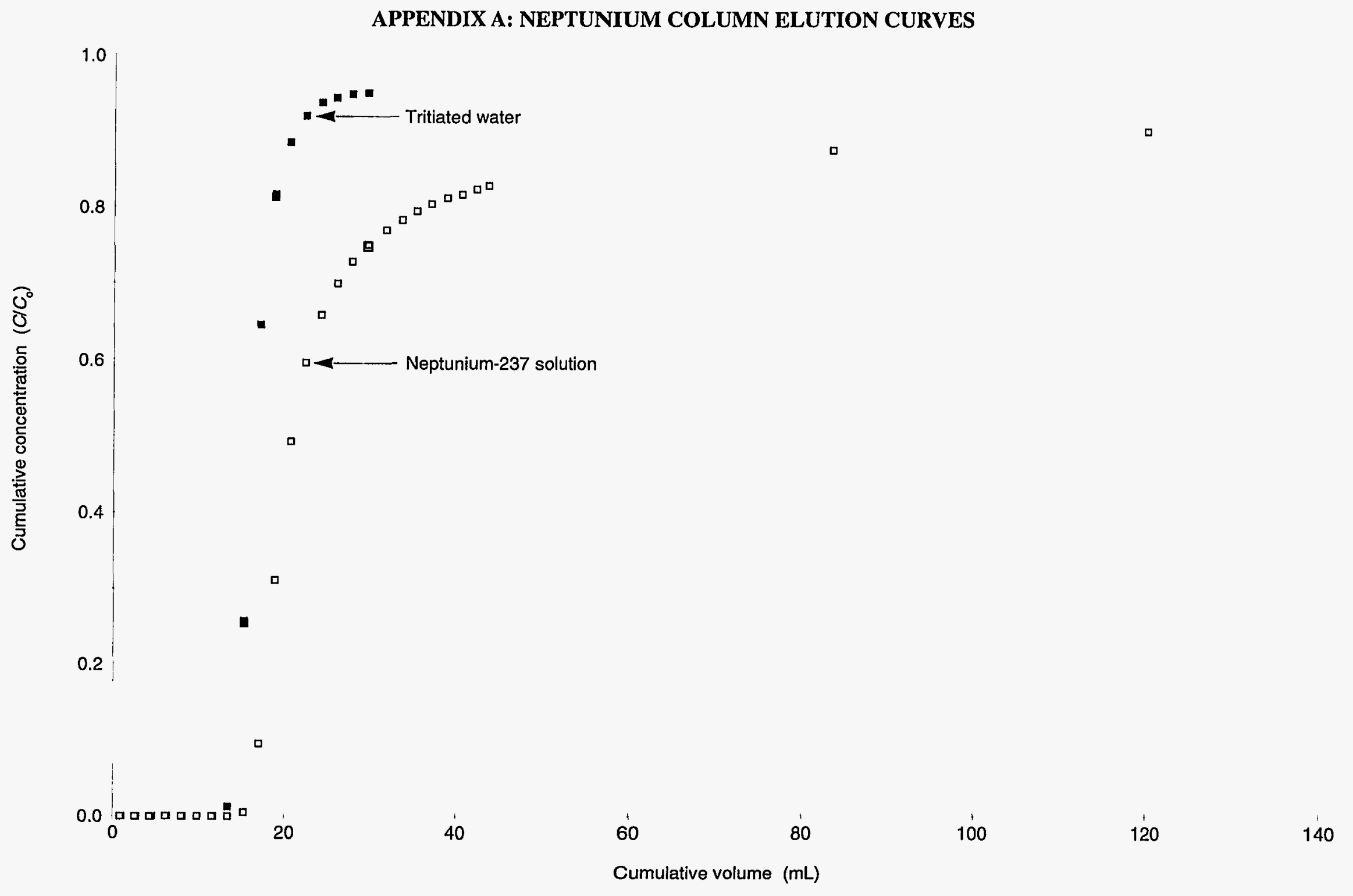

Column 19. Neptunium elution through vitric tuff GU3-1405 with synthetic UE-25 p\#1 water at $1.75 \mathrm{~mL} / \mathrm{hr}$ (Data source notebook: Crushed and Solid Rock Columns, TWS-INC-02-93-01, section AA) 